\title{
Raízes
}

\section{FORMAS COTIDIANAS DA RESISTÊNCIA CAMPONESA}

\author{
Tradução: Marilda A. de Menezes*** e Lemuel Guerra***
}

RESUMO

O artigo tem como objetivo revisar algumas teorias clássicas sobre o campesinato que privilegiam as greves, rebeliões, ações contra o estado, organizações institucionais como espaços de expressão política dos camponeses. Reconhece-se a importância destas ações no cenário político, no entanto, elas nos dizem pouco sobre a luta mais vital e cotidiana levada na fábrica pela jornada de trabalho, pelo salário, pela autonomia, por direitos e por respeito. Para muitos trabalhadores tais formas de luta cotidiana podem ser a única opção disponível. O artigo propõe um referencial teórico-metodológico para compreender este amplo leque de formas cotidianas, fragmentadas e difusas de resistência.

Palavras chave: política dos camponeses, resistência, cotidiano.

\section{ABSTRACT}

This article aims to review some classic theories about the peasantry which privilege strikes, rebellions, actions, events against the State and institutional organizations as spaces of peasant political expressions. These actions are acknowledged as very important in the political arena, however, they help very little to understand the everyday struggle in the factories shop-floor for reducing the labor journey, for wages, for autonomy, for rights and respect. These everyday forms of struggle can be the only option available for many workers. The article pursues to construct a theoretical and methodological reference to understand the large range of everyday, fragmented and diffused forms of resistance.

Key words: peasant politics, resistance, everyday life.

\section{A HISTÓRIA NÃO ESCRITA DA RESISTÊNCIA}

A discussão que apresentamos a seguir originou-se de uma crescente insatisfação com grande parte da produção recente - incluindo a minha - sobre o tema das rebeliões e revoluções camponesas. É por demais evidente que a incomum atenção para com as insurreições camponesas de larga escala foi, pelo menos nos Estados Unidos, estimulada pela guerra do Vietnã e por algo como um namorico da esquerda universitária com as guerras de libertação nacionais. Nesse caso, os interesses e as fontes materiais reforçavam-se, visto que os registros históricos e os arquivos eram os mais ricos precisamente naqueles momentos em que os camponeses chegaram a representar uma ame-

\footnotetext{
* James C. Scott, cientista político do Departamento de Ciências Políticas, Universidade de Yale. USA (Caixa Postal 3532 - Yale Station, New Haven, CT - 06520-3532, USA), é autor dos seguintes livros: Political Ideology in Malaysia: Reality and the Beliefs of an elite. (Ideologia Política na Malásia: realidade e crenças de uma elite.) New Haven, Yale University Press, 1968; Comparative Political Corruption. (Corrupção Política Comparada.) Englewood Cliffs, NJ, Prentice Hall, 1972; The moral economy of the peasant: rebellion and subsistence in southeast Ásia. (A economia moral dos camponeses: rebelião e subsistência no Sudeste asiático.) New Haven, Yale University Press, 1976; Weapons of the weak: everyday forms of peasant resistence. (Armas dos fracos: formas cotidianas de resistência camponesa...) New Haven, Yale University, 1985; Domination and the arts of resistence: hidden transcripts (Dominação e artes da resistência: transcrição oculta.) New Haven, Yale University Press, 1990; Seeing like state: how certains schemes to improve the human condition have failed. (Parecendo com o Estado: como certos esquemas para melhorar a condição humana falharam.) New Haven. Yale University Press, 1998. Para mais informação sobre a vida e obra de Scott, ver o artigo de Monsma, K., "James C. Scott e resistência cotidiana no campo: uma avaliação crítica". In: BIB, $\mathrm{N}^{\circ}$ 49, Rio de Janeiro, $1^{\circ}$ semestre de 2000, pp. 95-121 e o de Menezes, M. A., "O cotidiano camponês e sua importância enquanto resistência à dominação: a contribuição de James C. Scott", publicado neste número de Raízes.

** Professora do Programa de Pós-graduação em Sociologia da Universidade Federal de Campina Grande (PPGS/UFCG). E -mail: marilda@ch.ufpb.br; marildamenezes@uol.com.br.

**** Professor do Programa de Pós-graduação em Sociologia da Universidade Federal de Campina Grande (PPGS/UFCG). E-mail: lenksguerra@yahoo.com.
} 
aça ao Estado e à ordem internacional existente ${ }^{1}$. Em outros tempos, quer dizer, na maior parte do tempo, os camponeses apareceram nos registros da História não tanto como atores históricos, mas como contribuidores mais ou menos anônimos para as estatísticas sobre densidade populacional, impostos, migração da mão-de-obra, propriedade de terras e a produção agrícola.

O fato é que, apesar de toda sua importância para os lugares onde ocorreram, as rebeliões camponesas, deixando de lado as "revoluções" camponesas, são poucas e diversas. Não somente são comparativamente raras as circunstâncias que favorecem levantes camponeses de larga escala, mas também as revoltas por elas provocadas são quase sempre totalmente esmagadas. $\mathrm{Na}$ verdade, mesmo as revoltas que fracassaram podem representar algum ganho: algumas poucas concessões por parte do Estado ou dos proprietários de terras, uma breve pausa em relação a novas e dolorosas relações de produção ${ }^{2}$, e, pelo menos, uma memória da resistência e da coragem que pode servir para o futuro. Tais ganhos, porém, são incertos, enquanto o massacre, a repressão e a desmoralização da derrota são tão certos quanto reais.

Em grande medida, pode-se dizer que a historiografia da luta de classes tem sido sistematicamente distorcida em favor de uma posição centrada no Estado. Os eventos que chamam a atenção são aqueles que o Estado e as classes dominantes concordam em destacar em seus arquivos. Assim, por exemplo, uma pequena e fútil rebelião destaca-se tanto mais, quanto maior for o seu impacto sobre as relações de classe, enquanto os atos não anunciados de fuga, roubos, que podem ter um impacto muito maior são raramente noticiados. As pequenas rebeliões podem ter uma importância simbólica por sua violência e pelos seus objetivos revolucionários, mas, para a maioria das classes historicamente subordinadas, tais episódios raros foram mais momentâneos do que as silenciosas guerrilhas que têm lugar no cotidiano de várias populações. Possivelmente, talvez, no estudo da escravatura que tais formas de resistência têm recebido atenção e isto porque tem havido relativamente menos rebeliões escravas do que desejari- am os historiadores. Também é digno de registro que, mesmo naqueles momentos históricos em que uma revolta apoiada nos camponeses realmente teve sucesso na tomada do poder, os resultados foram, na melhor das hipóteses, uma vitória relativa para os camponeses. O que quer que seja que a revolução tenha alcançado, sempre criava um aparato estatal hegemônico mais coercitivo, sempre mais hábil em aumentar seus privilégios sobre a população rural do que nenhum outro que o precedeu. Freqüentemente, os camponeses se encontram na irônica situação de terem cooperado para a chegada de grupos dominantes ao poder, cujos planos de industrialização, taxação e coletivização se revelam diametralmente opostos aos objetivos pelos quais os camponeses pensavam que estavam lutando ${ }^{3}$.

Uma história dos camponeses que focalizasse apenas as insurreições seria mais como uma história de trabalhadores fabris dedicados inteiramente a greves gerais e a protestos. Embora possam ser importantes e sintomáticos, esses eventos nos dizem pouco sobre a arena mais durável dos conflitos de classes e da resistência: a luta mais vital/ cotidiana levada na fábrica pela jornada de trabalho, pelo direito ao lazer, pelo salário, pela autonomia, por direitos e por respeito. Para trabalhadores que operam, por definição, numa desvantagem estrutural e sujeitos à repressão, tais formas de luta cotidianas podem ser a única opção disponível. A resistência desse tipo não descarta os manifestos, os protestos e as batalhas mais rápidas que chamam a atenção, mas um território vital tem sido ganho e perdido também nela. Para os camponeses, pulverizados ao longo da zona rural e enfrentando ainda mais obstáculos para a ação coletiva e organizada, as formas cotidianas de resistência parecem particularmente importantes.

Por todas essas razões, ocorreu-me que a ênfase nas rebeliões camponesas estava mal colocada. Pelo contrário, pareceu mais importante considerar o que podemos chamar formas cotidianas de resistência camponesa - a luta prosaica, mas constante, entre os camponeses e aqueles que querem extrair deles o trabalho, o alimento, os impostos, os aluguéis e os lucros. A maioria das formas que

${ }^{1}$ Ver, por exemplo, Moore Jr., B. The Social Basis of Dictatorship and Democracy. Boston: Boston Press, 1966; Page, J.M. Agrarian Revolution: Social Movements and Export Agriculture in the Underveloped World. New York: Free Press, 1975; Wolf, E. R. Peasant Wars of the Twentieth Century. New Haven: Yale University Press, 1976; Popkin, S. L. The Rational Peasant (Berkeley: University of California Press, 1969).

2 Para um exemplo desses ganhos temporários, ver o ótimo estudo de Hobsbawm, E. J. e Rudé, G. Captain Swing. New York: Pantheon Books, 1968: 281-99.

${ }^{3}$ Alguns desses tópicos são focalizados em Scott, J.C. Revolution in the Revolution: Peasant and Commisars, Theory and Society, Vol. 7, Nos. 1, 2 (1979), pp. 97-134. 
essa luta toma cessa ao ser coletivamente desafiada. Aqui tenho em mente as armas comuns dos grupos relativamente sem poder: fazer "corpo mole", a dissimulação, a submissão falsa, os saques, os incêndios premeditados, a ignorância fingida, a fofoca, a sabotagem e outras armas dessa natureza. Essas formas brechtianas de luta de classe têm certas características em comum: requerem pouca ou nenhuma coordenação ou planejamento; sempre representam uma forma de auto-ajuda individual; evitam, geralmente, qualquer confrontação simbólica com a autoridade ou com as normas de uma elite. Entender essas formas comuns de luta é entender o que muitos dos camponeses fazem nos períodos entre as revoltas para melhor defender seus interesses.

Seria um grave erro, como acontece em relação às rebeliões camponesas, idealizar demasiadamente essas "armas dos fracos”. Elas provavelmente não poderão fazer mais do que afetar lateralmente as várias formas de exploração que os camponeses enfrentam. Além disso, os camponeses não têm o monopólio dessas armas, como podem atestar todos que tenham observado as maneiras pelas quais funcionários e latifundiários têm resistindo e obstaculizado as políticas estatais que lhes são desfavoráveis.

Por outro lado, tais modos brechtianos (ou Schwaikianos) de resistência não são insignificantes. A deserção e a evasão do recrutamento militar e da corvéia têm, indubitavelmente, limitado as aspirações imperiais de muitas monarquias do sudeste da Ásia ${ }^{4}$ e da Europa. O processo e seus impactos potenciais são capturados, como em nenhum outro trabalho, na abordagem de R. C. Cobb a respeito do projeto de resistência e de deserção na França pósrevolucionária e sob o Primeiro Império.

Do ano V ao VII, há um crescente número de relatórios, originados de vários departamentos..., a respeito de todo recruta vindo de dados lugares que retornaram para casa e que vivem nelas tranqüilos. Ainda melhor, muitos deles nunca retornaram para suas casas, porque, em primeiro lugar, nunca saíram delas... No ano VII, também, muitos dos dedos feridos das mãos direitas - a mais comum das auto-mutilações
- começaram a testemunhar estatisticamente a força do que pode ser descrito como um amplo movimento de cumplicidade coletiva, envolvendo a família, as paróquias, as autoridade locais e todas as comunidades.

Mesmo no Império, com uma polícia amplamente mais numerosa, abrangente e confiável, o máximo que o Estado conseguiu foi

diminuir temporariamente a velocidade da deserções, que, a partir de 1812, mais uma vez atingira proporções catastróficas. Não poderia ter havido um maior referendum concernente à impopularidade universal de um regime opressor e não houve um espetáculo mais encorajador para um historiador do que um povo que decide não mais lutar e que, sem pestanejar, volta para casa ... o povo comum, pelo menos nesse aspecto, teve sua parcela justa na derrubada de um dos mais temíveis regimes da França. ${ }^{5}$

Assim como a deserção têm sido uma estratégia de resistência popular, conforme o comentado acima, a evasão e sonegação de impostos têm sido usadas nos países do Terceiro Mundo e naqueles em desenvolvimento quer sejam pré-coloniais, coloniais ou independentes. Pouco se admira que uma tão grande parcela de impostos seja recolhida em países do Terceiro Mundo em forma de arrecadação sobre importações e exportações. O padrão é que, não em pequena medida, se elogie a capacidade de resistência dos sujeitos aos impostos. Mesmo uma leitura rápida da literatura sobre o desenvolvimento rural revela como uma rica safra e os esquemas de programas impopulares de governos têm sido levados à extinção pela resistência passiva dos camponeses ${ }^{6}$. Em algumas ocasiões, essa resistência tem se tornado ativa e até mesmo violenta. A regra geral, porém, é a forma de resistência passiva, expressa através de sabotagens sutis, de não participação, de evasão e de engano. O permanente esforço do governo colonial da Malaya para desencorajar os camponeses de aumentar a produção de borracha, que poderia competir com o setor de plantation,

\footnotetext{
${ }^{4}$ Veja a narrativa e análise de Adas, M. "From Avoidance to Confrontation: Peasant Protest in Precolonial and Colonial Southeast Asia”, Comparative Studies in Society and History, Vol. 23, No.2 (April 1981), pp. 217-47.

${ }^{5}$ Cobb, R. C. The Police and the People: French Popular Protest, 1789-1820. Oxford: Clarendon Press, 1970: 96-7. Para uma abordagem consistente da auto-mutilação como estratégia para evitar a convocação, ver Zola, É. La Terre, traduzido por Douglas Parnce, Harmondsworth: Penguin, 1980

${ }^{6}$ Para uma fascinante abordagem de uma resistência dessa natureza na Tanzânia, ver Hyden, G. Beyond Ujamar in Tanzania. Londres: Heinneman, 1980. Sobre as conseqüências de um visão limitada de políticas agrárias impostas de cima para baixo, ver, Bates, R. Markets and States in Tropical Africa: The Political Basis of Agricultural Policies Berkeley: University of California Press, 1981.
} 
principalmente pela terra e pelos mercados, é um caso exemplar ${ }^{7}$. Vários esquemas de restrições e de legislações sobre o uso da terra foram testados no período de 1922 a 1928 e, mais uma vez, na década de 30, todos com resultados modestos, devido à massiva resistência dos camponeses. Os esforços dos camponeses, em estados com estilos próprios de socialismo, para impedir e enfraquecer, ou mesmo destruir formas anti-populares de agricultura coletiva, representam um exemplo marcante das técnicas defensivas disponíveis para um campesinato muitas vezes encurralado. Outra vez, a luta é menos marcada por confrontações massivas e desafiadoras do que por uma evasão que é igualmente massiva e freqüentemente muito mais eficaz.

O estilo de resistência aqui focalizado pode ser, possivelmente, melhor entendido em contraste com outras formas de resistência, possuidoras dos mesmos objetivos. A primeira forma é a resistência cotidiana no sentido já acima demonstrado. A segunda, a confrontação direta, que tem dominado o estudo da resistência camponesa. Naquela, encontramos um processo sorrateiro, através do qual os camponeses "intrusos" têm freqüentemente invadido plantações e florestas estatais; nesta, temos invasões públicas de terras que desafiam abertamente as relações de propriedade. Associadas à primeira forma, temos a gradual deserção militar e os furtos silenciosos de celeiros públicos ou privados; associadas à segunda forma de resistência, temos a realização de motins, objetivando eliminar ou substituir oficiais militares, e a invasão de feiras e de celeiros, visando redistribuir o suprimento de alimentos.

Tais técnicas de resistência são adequadas às características particulares do campesinato. Sendo uma classe diferente dos outros setores classificados como de classes baixas, distribuídos geograficamente, freqüentemente sem uma liderança e sem disciplina que pudessem encorajar uma oposição de caráter mais organizado, o campesinato está mais propenso às lutas do tipo "guerrilha", que requerem pouca ou nenhuma coordenação. Assim, seus atos individuais de pequenos furtos e de deserção do exército, freqüentemente reforçados por uma venerada cultura da resistência, podem tornar completamente inócuas as políticas inventadas pelos seus supostos superiores no sistema capitalista. O proponente dessas políticas, o estado pode responder a essa resistência de várias maneiras: (1)novas políticas podem ser elaboradas a partir de novas expectativas mais realistas; (2) algumas dessas políticas podem ser mantidas e reforçadas com incentivos positivos, objetivando o encorajamento de um comprometimento voluntário; e, é claro, pode simplesmente escolher empregar mais coerção. Qualquer que seja a resposta adotada, devemos lembrar o fato de que a ação do campesinato tem se transformado ou limitado as opções de políticas disponíveis. Assim, é dessa maneira e não através de revoltas ou da pressão política legal que o campesinato tem classicamente marcado presença política. Por conseguinte, toda história ou teoria da ação política dos camponeses que queira fazer justiça ao campesinato como ator histórico deve, necessariamente, ajustar suas contas com o que estamos chamando de "formas cotidianas de resistência". Por essa razão, é importante tanto documentar quanto trazer alguma ordem conceitual a esse aparente caos da atividade humana.

As formas cotidianas de resistência camponesa não produzem manchetes de jornais. Assim como milhões de pólipos de antozoários criam um arrecife de corais, milhões e milhões de atos individuais de insubordinação e de evasão criam barreiras econômicas e políticas por si próprios. Há raramente alguma confrontação dramática, eventualmente digna de ser noticiada. E, sempre que o barco do estado esbarra numa dessas barreiras, a atenção é centrada no acidente e não na vasta agregação de micro-atos que resultaram na barreira. É muito raro que os produtores desses micro-atos busquem chamar a atenção sobre eles mesmos. Sua segurança está no seu anonimato. Também é extremamente raro que os oficiais do estado desejem dar publicidade a essa insubordinação ${ }^{8}$. Fazê-lo seria admitir que sua política é impopular e, acima de tudo, expor a dureza de sua autoridade no campo - duas possibilida-

${ }^{7}$ A melhor e mais completa análise desse tema pode ser encontrada em Ghee, L. T. Peasants and their Agricultural Economy in Colonial Malaya, 1874-1941. Kuala Lampur: Oxford University Press, 1977. Ver também o persuasivo argumento de Donald M. Nonini, Paul Diener, e Eugene E. Robkin, "Ecology and Evolution: Population, Primitive Acumulation and the Maly Peasantry", manuscrito, 1979.

${ }^{8}$ Um exemplo clássico disso é a campanha de coletivização soviética, na qual a ampla oposição à adesão ao Kolkhoz nunca tinha sido tornada pública, até que foi dada a autorização oficial de Stalin, no seu discurso de maio de 1930, intitulado "Veloz e bem sucedido". Antes disso, ninguém poderia imaginar que tinha sido utilizada coerção (o eufemismo para coerção era "ordenação burocrática"), que uma enorme exaustão dos rebanhos de gado aconteceu como resposta à campanha, ou, finalmente, que a oposição à coletivização tivesse sido tão forte entre os camponeses quanto entre os kulaks. Ver Davies, R.V. 
des que não interessam de maneira nenhuma ao estado? A natureza dos fatos e a mudez auto-interessada dos antagonistas contribuem para criar um tipo de silêncio cúmplice, que exclui totalmente as formas cotidianas de resistência dos registros históricos.

A História e as Ciências Sociais, escritas por uma intelectualidade com base em registros escritos, ao quais, por sua vez, são também, em grande medida, originados por autores oficiais, simplesmente não estão bem equipadas para desvelar as formas silenciosas e anônimas das lutas de classes que caracterizam o campesinato ${ }^{10}$. Nesse caso, os estudiosos, implicitamente, juntam-se à conspiração dos participantes, que são, eles mesmos, como foram no passado, silenciados. Coletivamente, essa conspiração improvável contribui para a estereotipação dos camponeses, que têm sido idealizados, tanto na literatura quanto na História, como uma classe que alterna longos períodos de abjeta passividade com breves, violentas e fúteis explosões de ira. Um exemplo clássico de discurso literário sobre o camponês médio é o que vemos a seguir:

Ele tinha séculos de medo e de submissão atrás dele, suas costas tornaram-se resistentes a explosões, sua alma tão destruída que ficou incapaz de reconhecer usa degradação. Pode-se batê-lo e deixá-lo faminto e roubar-lhe tudo, ano após ano, antes que ele pudesse abandonar sua precaução e estupidez, sua mente cheia de todos os tipos de idéias confusas que ele não poderia compreender bem; e isso continuou até que a culminação da injustiça e do sofrimento lançou-o à garganta de seu patrão como um animal doméstico enfurecido que tinha sido submetido a espancamentos demasiados [Zola, 1980: 91].

Na visão de Zola, há apenas um pouco de verdade. É certo que o comportamento público dos camponeses, durante os tempos da quietude, produz um retrato de submissão, medo e precaução. Em contraste, as insurreições camponesas parecem reações viscerais de fúria cega. $\mathrm{O}$ que falta à abordagem da passividade "normal" é a lenta, subterrânea e calma luta contra os aluguéis, as colheitas, o trabalho e os impostos, nas quais a submissão não passou de uma cena - de uma tática necessária. Assim, convém esclarecer que está ausente da descrição do período das "explosões" a visão subjacente de justiça que as informa e seus alvos e objetivos específicos, que são freqüentemente muito racionais. As “explosões” nelas mesmas são freqüentemente sinais de que as formas "normais" de lutas de classes estão decrescendo ou entraram em crise. Tais declarações abertas de guerra, com seus riscos mortais, normalmente acontecem depois de um demorado enfrentamento num terreno diferente.

\section{DOIS EXEMPLOS EMBLEMÁTICOS}

No interesse de dar conta das questões analíticas levantadas pelas formas cotidianas de resistência, ofereço uma breve descrição de dois exemplos, dentre os muitos encontrados no curso do trabalho de campo, realizado no período entre 1978 e 1980, em uma vila da Malásia, destacada produtora de arroz. O primeiro exemplo envolve uma tentativa de boicote de proprietários que contrataram colhedeiras automáticas para substituir o trabalho manual, levada a cabo por parte de grupos de mulheres que transplantavam mudas de arroz. O segundo diz respeito a um padrão de furtos anônimos de estoques de grãos de arroz que parece ter crescido em freqüência. Cada uma dessas duas atividades tem a marca característica da resistência cotidiana. Nem o boicote, como veremos, nem os furtos apresentam qualquer desafio público ou simbólico da legitimidade da propriedade e da organização da produção. Nenhum dos dois requereram qualquer organização formal e, no caso dos furtos de estoques de grãos de arroz, a maior parte das atividades foi realizada individualmente na calada da noite. Talvez a característica mais importante dessas e de muitas outras atividades semelhantes ocorridas no campo é que, em strictu senso, elas não têm autores que assumiriam a responsabilidade pública por sua realização.

\section{O PANO DE FUNDO}

Antes de examinar mais profundamente os dois exemplos de resistência acima mencionados, um breve perfil da

The Socialist Offensive: The Collectivisation of Soviet Agriculture, 1928-1930. London: Macmillan, 1980: caps. 6 e 7.

${ }^{9}$ Cabe destacar que que essa "rejeição" a tais possibilidades não se dá de forma total. Registros no nível dos distritos são capazes de se provar dúbios esse respeito, já que os oficiais tentam explicar o insucesso mencionando o recebimento de impostos ou as estatísticas do recrutamento militar aos seus oficiais superiores da capital. Imagina-se também que os registros orais informais são abundantes. Exemplos disso seriam as reuniões informais do gabinete ou do ministério, programadas para lidar com o fracasso de políticas causadas pela insubordinação rural.

${ }^{10}$ A exceção parcial a ser feita é, claro, a Antropologia. 
zona rural em questão e de sua história econômica recente deverá ajudar no entendimento de nossa abordagem. A aldeia que chamaremos de Sedaka é uma comunidade de aproximadamente 74 propriedades (352 pessoas), localizada sobre a planície de Muda, no estado de Kedah, na Malásia. A região de Muda tem sido, desde o século XIV, a principal área produtora de arroz da península, sendo seu cultivo a sua principal atividade econômica. A estratificação de Sedaka pode ser lida, para qualquer das finalidades práticas, através dos dados referentes às terras de cultivo de arroz e ao tamanho das fazendas. A parte pobre da comunidade, em 1979, possuía apenas 3\% das terras dedicadas ao cultivo de arroz da região e plantava o equivalente a $18 \%$ do total da área ocupada com esse tipo de produção. A média de extensão das fazendas da metade pobre da comunidade era pouco mais de 1 acre, menos da metade do que é julgado necessária para prover um padrão mínimo de vida para uma família de 4 membros, em uma área de cultivo de arroz. Dez famílias estão literalmente sem terra e mais da metade dos proprietários de Sedaka tem renda abaixo da linha da miséria estabelecida pelo governo. No outro pólo da estratificação estão dez proprietários, que possuem mais da metade da terra da região dedicada ao plantio de arroz e cultivam uma média de mais de oito acres. Esses proprietários constituem a elite econômica da comunidade, sendo que, sete deles pertencem ao partido dominante malasiano, o UMNO, o que lhes permite controlar também a pacata vida política da região.

Para nossos propósitos aqui, consideramos como a maior mudança na vida sócio-econômica de Sedaka, durante o período entre 1970 e 1980, o início da dupla safra e a mecanização das colheitas de grãos de arroz que veio em sua decorrência. A dupla safra foi, nela mesma, algo como que um boom para todos os estratos da comunidade: arrendadores ganharam o dobro; trabalhadores alugados e arrendatários aumentaram sua renda anual; e até as miseráveis 28 famílias, que dependiam do trabalho no campo para obter uma parte substancial de sua renda, prosperaram como nunca, deslocando-se de acordo com a necessidade de mão de obra, participando, então, de duas colheitas anuais. Durante um curto período de euforia, as casas foram reconstruídas e consertadas, chefes de famíli- as que tinham partido cedo para encontrar trabalho na entre-safra puderam voltar para casa e todos tiveram arroz suficiente para alimentar suas famílias ao longo de todo o ano. No entanto, outro efeito da dupla-safra, mais precisamente da introdução de máquinas coletoras, foi a diminuição da renda dos habitantes mais pobres da região.

Em 1975, virtualmente todos os arrozais em Muda eram cortados e debulhados manualmente. No final dos anos 70, grandes máquinas de estilo ocidental, custando em torno de $\mathrm{M} \$ 200,000$, possuídas por grandes sindicatos de homens de negócios, já eram responsáveis por $80 \%$ da colheita de arroz. Se é difícil imaginar o impacto visual desse estonteante salto tecnológico - das foices e canos das debulhadoras para barulhentos gigantes com 32 barras cortadoras - sobre o campesinato, não é tão difícil calcular seu impacto sobre a distribuição da renda no campo. As receitas dos trabalhadores dos arrozais foram reduzidas quase à metade, já que restou a atividade de transplantar como a única maior operação que ainda requeria trabalho manual. Certamente as perdas em termos de renda foram maiores entre aqueles mais pobres: pequenos proprietários, arrendatários marginais e, sobretudo, todos os sem terra com salário mínimo. Se o impacto da mecanização for somado à estagnação dos preços para os produtores, além do aumento dos custos de matéria-prima e dos preços ao consumidor, os mais pobres chefes de família de Sedaka perderam quase todos os ganhos originais da dupla safra. Assim, enquanto a distribuição de renda tem piorado significativamente, os ganhos das duplas-safras têm ido largamente para os grandes fazendeiros, detentores da maior parte da terra e do capital local.

Como acontece com muitas mudanças tecnológicas, os efeitos secundários da mecanização da colheita têm sido pelo menos tão importantes quanto seus efeitos primários. Resumindo ao essencial, as maiores conseqüências da mecanização da colheita podem ser assim enunciadas ${ }^{11}$ :

1) Virtual eliminação da prática de apanhar grãos deixados no campo ${ }^{12}$ quando do trabalho da colheita e do moer dos talos que ficavam anteriormente dos lados dos tubos das debulhadoras, atividades que forneciam um alimento subsidiário para muitas famílias pobres da comunidade;

${ }^{11}$ Para uma abordagem mais profunda desse ponto, ver Scott, C. J. Formas cotidianas de resistência camponesa. New Haven: Yale University Press, 1985, Caps. 3 e 4.

12 Tradução de gleaning, verbo de difícil equivalência em português, que significa apanhar grãos deixados no campo quando do trabalho da colheita. 
2) Favorecimento da substituição do transplante pela semeadura manual, já que a máquina poderia colher mais facilmente arrozais de tamanho e grau de maturidade irregulares. Em torno de 1980 quase a metade das áreas dos arrozais eram semeados dessa maneira, eliminando assim muito do emprego do transplante manual;

3) Redução acentuada da demanda por trabalhadores para a colheita, permitindo a redução nas taxas de saláriomínimo dos trabalhadores ainda disponíveis;

4) Criação de melhores condições, para os maiores proprietários de dentro e de fora da comunidade, para a demissão de arrendatários a quem tinham alugado lotes de terras e a diminuição da participação destes no cultivo, pela possibilidade de alugar os serviços das máquinas;

5) Surgimento de uma nova classe de ricos empresários: a dos arrendatários de terras, capazes de alugar grandes áreas ao mesmo tempo por muitas temporadas, pagando adiantado a quantia total.

As transformações no cultivo de grãos de arroz, desde 1971, não resultaram somente num relativo empobrecimento dos camponeses mais pobres, mas também influenciaram na produção da sua marginalização, pelo menos no que se refere às relações de produção. Até 1975 , ricos arrendatários e fazendeiros tinham mais arrozais do que eles próprios podiam cultivar. Assim, precisavam de arrendatários, de serviços de aragem, transplantadores, ceifadores e debulhadores. Para assegurar uma oferta confiável de mão-de-obra, era comum, entre os mais ricos proprietários, a benevolência com a força de trabalho bem como seu acesso à terra. Essa benevolência se manifestava na promoção de festas ocasionais, pela estensão do bônus do zakat (o dízimo islâmico) aos trabalhadores das colheitas, através de pequenos empréstimos ou presentes e, sobretudo, pelo cultivo de um comportamento social diplomático. Com a introdução das novas tecnologias mencionadas, o bem estar dos grandes proprietários pouco se relaciona com os pobres arrendatários ou trabalhadores, diminuindo sua motivação para continuar a cultivar a benevolência acima citada. Assim, a marginalização dos trabalhadores é refletida num marcante declínio na promoção de festas, na diminuição do zakat e da caridade, e no refluxo do respeito público aos pobres, por parte dos ricos.

\section{OBSTÁCULOS À RESISTÊNCIA COLETIVA E ABERTA}

A despeito dos reveses econômicos experienciados pelos pobres de Sedaka e da deterioração da qualidade das relações entre classes, evidentes nos bastidores, nessa re- gião não se têm constituído instâncias explícitas de conflitos de classes. As razões pelas quais esse silêncio público tem prevalecido são dignas de uma menção breve, precisamente pelo fato de que elas são, ao meu ver, comuns a muitos contextos de relações de classes no campo, o que sugere que o tipo de resistência que encontraremos aqui é uma regra e não a exceção. A situação que os pobres enfrentam em Sedaka e na planície de Muda é, finalmente, parte de uma luta ubíqua e inusitada contra os efeitos do desenvolvimento capitalista no campo: a perda de acesso aos meios de produção (a proletarização), a perda do trabalho (a marginalização) e da renda, e a perda do pequeno respeito e das reivindicações sociais reconhecidas, que se foram com o seu status prévio. A maioria dos textos de história sobre o desenvolvimento capitalista, ou uma simples olhada sobre os conflitos neste contexto, indicariam que essa luta é uma causa perdida. E bem que isto pode ser quase assim. Se for, os pobres camponeses de Sedaka se encontram em uma numerosa e distinta companhia histórica. A resistência silenciosa das vítimas neste caso pode ser entendida através de dois conjuntos de razões: o primeiro refere-se à natureza das mudanças enfrentadas pelos pobres, e as que aconteceram pela natureza de sua comunidade, enquanto que o segundo se refere aos efeitos da repressão.

As formas de resistência em Sedaka refletem as condições e limitações sob as quais elas se geraram. Assim, se a resistência é aberta, raramente é coletiva. Se são coletivas, raramente são abertas. Aqui a analogia com a guerrilha de pequena escala e defensiva dos skirmishes é, mais uma vez, apropriada. Os encontros raramente são mais que "incidentes". Os resultados são inconclusivos e os agentes se movem sob a proteção da escuridão e do anonimato, misturando-se no meio da população civil também para evitar retaliações.

Talvez o dado mais importante que estrutura as opções abertas aos pobres de Sedaka seja simplesmente a natureza das mudanças que eles têm experimentado. Alguns tipos de mudanças, quando algumas variáveis permanecem iguais, são mais explosivos que outros - são mais susceptíveis de provocar enfrentamentos abertos e coletivos. Nessa categoria, podemos colocar aquelas mudanças massivas e repentinas que destróem, decisivamente, quase todas as rotinas da vida cotidiana e, simultaneamente, ameaçam a sobrevivência da maioria da população. Em Sedaka, contudo, a maioria das mudanças que constituem a revolução verde tem sido experimentada como uma série de gradativas mudanças no direito de posse e na tecnologia. As 
dolorosas mudanças tenderam a se instalar gradualmente e a atingir, inicialmente, apenas uma pequena minoria dos camponeses. Quando os proprietários decidiram diminuir o cultivo deles mesmos ou arrendar suas terras para ricos operadores comerciais, somente poucos arrendatários foram ameaçados e suas dificuldades, à primeira vista, pareciam mais infortúnios individuais do que propriamente uma tendência geral. Isso também pode ser dito do aumento dos aluguéis e da substituição da semeadura manual pelo replante. Os parafusos eram apertados pouco a pouco e com velocidade variada, de forma que as vítimas não eram mais do que um pequeno grupo de cada vez. Neste e em outros casos, cada proprietário/fazendeiro, ao fazer mudanças, representava uma situação particular que confrontava um ou, no máximo, poucos indivíduos.

A única exceção a esse modelo foi a introdução de máquinas de ceifar e colher, o que, como veremos, provocou a ação mais próxima de produzir um enfrentamento aberto e coletivo. Mesmo neste caso, contudo, o impacto não foi instantâneo, nem completamente despido de uma certa ambigüidade para muitos na aldeia. Para as duas primeiras temporadas, o impacto econômico sobre os pobres foi notado, mas não devastador. Camponeses médios ficaram genuinamente divididos entre a provável vantagem de fazer suas colheitas mais rapidamente e a possibilidade de perdas salariais para alguns de seus filhos. Em nenhum único momento a mecanização da colheita representou uma ameaça coletiva à sobrevivência de uma sólida maioria de camponeses.

Outra característica significativa das transformações agrícolas em Kedah, que serve muito poderosamente para diluir conflitos de classes, é o fato de que elas simplesmente removem os pobres do processo produtivo, ao invés de significar uma exploração direta deles. Um após o outro, os grandes fazendeiros e proprietários do Esquema Mude têm eliminado terrenos de lutas potenciais referentes à distribuição das colheitas e dos lucros do cultivo de grãos de arroz. Por sua vez, substituindo as negociações a respeito do preço do corte e debulhe, há agora somente um pagamento único ao operador da máquina. No lugar das negociações a respeito dos custos de replante, há a opção de semear os grãos manualmente e evitar, desse modo, inteiramente o conflito. Finalmente, em vez de disputas tensas pelos prazos e preços dos aluguéis, há uma crescente alternativa de alugar as máquinas e trabalhar isoladamente ou de arrendá-las para um outro por uma quantia maior. Certamente, as mudanças e si mesmas, como demitir um trabalhador, passar a utilizar máquinas - não são simples de realizar. Mas, uma vez realizadas, o ex-arrendatário ou ex-trabalhador simplesmente deixa de ser relevante; não existem lutas posteriores, temporada a temporada, porque os pobres tornam-se redundantes. Uma vez que a conexão entre as lutas e o reino da produção se quebra, é também um problema simples quebrar a conexão - e as lutas - no reino do ritual, da caridade e mesmo da sociabilidade. Esse aspecto central da revolução verde, por ele mesmo, é capaz de contribuir para explicar a relativa ausência da violência de massa, em Kedahr e em outros lugares. Se os ganhos da revolução verde tivessem dependido de uma maior extração dos arrendatários, ao invés de implicado em sua demissão, ou da extração de mais trabalho com menores remunerações dos trabalhadores, as conseqüências para os conflitos de classe certamente seriam bem mais dramáticas. Assim, os lucros da dupla colheita dependem bem menos da exploração dos trabalhadores do que de ignorá-los ou substituí-los. Os conflitos de classe, como qualquer outro conflito, acontecem em um lugara sala destinada à operação de debulhar, na linha de montagem, o lugar onde o preço da empreitada e/ou do aluguel são acordados - onde interesses vitais estão em jogo. O que a dupla colheita tem produzido é a neutralização mais massiva dos lugares onde os conflitos de classe têm ocorrido historicamente.

Um obstáculo relacionado aos protestos abertos está já implícito no gradual impacto da dupla colheita. Assim como no caso desta, o impacto de cada uma das mudanças que temos discutido é mediado pela altamente complexa e justaposta estrutura de classes de Sedaka. Há arrendatários pobres e outros bem sucedidos; há proprietários (ou seus descendentes) que são também arrendatários e trabalhadores; há pequenos proprietários que necessitam do trabalho assalariado para sobreviver, mas que também alugam as máquinas de ceifar e colher. Dessa forma, cada uma das importantes mudanças que acontecem no arrendamento e na produção cria não somente vítimas e beneficiários, mas também um estrato substancial, cujos interesses não são tão facilmente discernidos. Sedaka não é Morelos, onde um campesinato pobre e indiferenciado enfrenta um inimigo comum nas plantações de açúcar. Isto acontece apenas em raras circunstâncias, nas quais a estrutura de classes no campo é tal que ou produz uma única clivagem ou uma quase uniforme resposta à pressão exterior. A situação em Sedaka é, acredito, a mais comum. A alta complexidade da estrutura de classe local milita, na maioria das questões, contra a opinião e a ação coletiva.

Raízes, Campina Grande, vol. 21, nº 01, p. 10-31, jan./jun. 2002 
Os obstáculos à ação coletiva apresentados pela estrutura de classes local são compostos por outras clivagens e alianças que atravessam as classes. Essas clivagens e alianças são constituídas, por um lado, pelos laços familiares, de parentesco, de facções ou de patronagem e, por outro lado, pelos laços rituais que turvam as águas das classes em virtualmente qualquer pequena comunidade. Quase sem exceção, pela criação de relações de dependência que restringem a ação dos homens e mulheres prudentes, esses laços operam, em termos de classes, a favor dos fazendeiros ricos.

Para não deixar a impressão, pelo que já foi mencionado, de que os obstáculos aos conflitos de classe em Sedaka são inteiramente problemas oriundos da complexa estratificação local e do caráter gradual das mudanças nas relações de produção, apresso-me em adicionar que a repressão real e potencial estão também muito envolvidas. É fácil notar que os esforços populares para parar ou impedir o crescimento da mecanização da colheita ocorreram num clima de medo, gerado pelas elites locais, pela polícia, por "ramificações especiais" das forças internas de segurança e, finalmente, por um determinado padrão de prisões e intimidações políticas. A atividade política aberta foi tanto rara quanto firmemente reprimida. Uma manifestação popular em Alor Star, a capital do estado, no começo dos anos 80 , reivindicando uma política de preços mais favoráveis para os grãos de arroz, foi recebido com a prisão de vários líderes oposicionistas, ameaças de detenção e promessas de ações ainda mais draconianas, caso os protestos continuassem. O medo de represália ou da prisão foi explicitamente mencionado por muitos como a razão de manter uma baixa mobilização.

Um obstáculo final ao conflito aberto pode ser denominado de "a dureza do cotidiano". A perspectiva que tenho em mente pode ser melhor expressa nas palavras de Hassan, um homem pobre que recebia aquém do salário mínimo para organizar pilhas de grãos de arroz. Ao ser perguntado porque ele não dizia "não" ao seu rico patrão, ele respondeu: "Os pobres não podem reclamar; quando estou doente ou precisando de trabalho, posso precisar dele outra vez. Fico com raiva no meu coração”. O que está operando, nesse caso, é algo que Marx, apropriadamente, chamou de "entorpecimento das relações econômicas" - uma compulsão que ocorre unicamente contra um passado de repressões esperadas (Marx, 1970:737). Na falta de qualquer possibilidade real, no presente, de transformar diretamente e coletivamente sua situação, os camponeses pobres não têm quase nenhuma escolha, a não ser ajustar-se às circunstâncias que eles enfrentam diariamente. Os arrendatários podem se ressentir amargamente do aluguel que têm que pagar por seu lote, mas precisam pagá-lo ou perdem a terra; o iminente sem terra pode deplorar a perda do salário-mínimo, mas precisam lutar pelas poucas oportunidades disponíveis; eles podem abrigar profundas animosidades contra as "panelinhas" que dominam a política da comunidade, mas devem agir com circunspecção, caso queiram receber benefícios de qualquer das pequenas vantagens que aquelas podem oferecer.

Pelo menos dois aspectos dessa adaptação pragmática e forçada às realidades merecem ênfase. $\mathrm{O}$ primeiro, o fato de que essa adaptação não exclui certas formas de resistência, embora coloque limites que somente os precipitados transgrediriam. O segundo, o fato de que, ela é, sobretudo, pragmática; ela não implica um consentimento normativo daquelas realidades. Entender isso é simplesmente compreender o que é, historicamente e em todas as suas possibilidades, a situação para a maioria das classes. Elas lutam sob condições que são amplamente independentes de sua determinação e, assim, suas necessidades materiais prementes precisam de algo como a acomodação diária a essas condições. Se muito do comportamento público de acomodação diária dos pobres de Sedaka reflete as realidades de relações de poder imediatas, não há necessidade, certamente, de assumir que isto é resultado de algumas hegemonias simbólicas e, por que não dizer, do consenso. A obrigatoriedade do cotidiano é, em si mesma, suficiente ${ }^{13}$.

\section{O ESFORÇO PARA PARAR AS MÁQUINAS}

A introdução das máquinas coletoras, a mais repentina e devastadora das mudanças associadas à dupla colheita, também atiçou a resistência mais ativa. Essa resistência foi bem além dos debates a respeito de sua eficiência, das reclamações referentes às perdas salariais e da difamação contra aqueles que alugaram as máquinas. Em toda a área da produção de arroz em Kedar, houve esforços fí-

${ }^{13}$ É importante notar que nem a repressão total nem a dureza do cotidiano seria tão eficaz, na restrição das opções, se os camponeses da Planície de Muda tivessem realmente acuados. Graças ao florescimento do setor urbano na Malásia, um certo número daqueles mais prejudicados pela dupla colheita pode exercitar a resposta histórica dos camponeses à opressão: a fuga. Se essas alternativas não existissem, o mesmo nível de repressão seria, indubitavelmente, menos eficaz. 
sicos para obstruir sua entrada dessas máquinas nos campos, por exemplo, os incidentes de sabotagem, os incêndios premeditados e os amplos esforços de organização de greves de transplantadores contra aqueles que primeiro alugaram as máquinas. Todas essas ações finalmente falharam na tentativa de impedir a mecanização da colheita de grãos de arroz, embora as tenham, indubitavelmente, limitado e adiado de alguma maneira.

A sabotagem e a obstrução das começaram a ocorrer no início dos anos 70, quando umas poucas e pequenas máquinas experimentais foram usadas em testes no campo. Contudo, somente em 1976, contudo, que as máquinas de colher de larga escala comercial entraram em operação, gerando contra si atos de violência. Os oficiais do Departamento de Desenvolvimento Agrícola de Muda optaram por classificar simplesmente de "vandalismo" atos como, por exemplo, o de remover baterias das máquinas e jogá-las dentro das valas de irrigação; o de destruir carburadores e outras partes vitais das máquinas, tais como distribuidores e filtros de ar; o de jogar areia e lama nos tanques de gasolina, e vários objetos (pedras, arame, pregos) dentro das brocas, dentre outros ${ }^{14}$. Em um bom número de comunidades, rumores velados de possíveis violências persuadiram muitos dos grandes fazendeiros a hesitar antes de alugar uma máquina. Tais táticas, em uma determinada comunidade, realmente impediram o uso de qualquer máquina coletora por três safras. Dois aspectos dessa sabotagem e ameaças associadas merecem uma ênfase particular. Primeiro, era claro que o objetivo dos sabotadores não era simplesmente o furto, porque nada foi realmente roubado. Segundo, todas as sabotagens foram realizadas à noite, por indivíduos ou pequenos grupos atuando anonimamente. Eles eram, além do mais, protegidos por seus vizinhos, que, se soubessem quem estava envolvido, afirmavam total ignorância quando a polícia realizava investigações. Como resultado, nenhum processo foi jamais instaurado. A prática de colocar vigilantes noturnos para vigiar as máquinas datam desses primeiros testes pelos quais passou a introdução da nova tecnologia de colheita.

Ao mesmo tempo, iniciou-se um silencioso, mas coletivo, esforço de mulheres para fazer pressão sobre os fa- zendeiros que alugassem máquinas. Os homens e mulheres, freqüentemente da mesma família, tinham perdido seu trabalho para as máquinas coletoras, mas somente as mulheres ainda possuíam um real poder de barganha. Ambos estavam, ainda naquele momento, no controle do transplante. Antes da introdução das máquinas coletoras, o grupo de mulheres (ação kumpulan) colhia nos campos que tinham também transplantado. Com a introdução da nova tecnologia, elas estavam perdendo quase a metade de seus salários sazonais e, compreensivelmente, se ressentiram de transplantar a produção de um fazendeiro que usaria a máquina coletora no período da colheita. Dessa forma, em Sedaka e, aparentemente, em toda a região de Muda, tais mulheres resolveram organizar um boicote que impediria o serviço de transplantar para os empregadores que alugassem as máquinas.

Dentre cinco "grupos de partilha” em Sedaka, três fizeram algumas tentativas para forçar o boicote. Cada grupo dentre esses três grupos era composto por seis a nove mulheres de quaisquer das comunidades. Os dois grupos que não participaram diretamente do boicote, recusaramse a quebrá-lo, não aceitando participar em plantios de fazendeiros que estivessem sendo "boicotados" por um dos outros três grupos. O porquê dos grupos das senhoras Rosni, Rokiah e Mariam terem tomado a iniciativa não está inteiramente claro. Eles são compostos por mulheres de famílias que são, em média, um pouco mais pobres do que aquelas das mulheres dos grupos restantes. Se nos basearmos em explicações locais dos padrões de resistência, o consenso é o de que Rosni, Rokiah e Mariam dependem fortemente do salário mínimo para sustentar suas famílias e são, ao mesmo tempo, "corajosas" (berani) $)^{15}$.

$\mathrm{O}$ boicote realmente representou uma forma muito cautelosa de resistência, não tendo havido, em nenhum momento, uma confrontação aberta entre fazendeiros que usavam as máquinas e seus transplantadores. Pelo contrário, eram empregadas abordagens anônimas e indiretas de rumores e insinuações (cara sembunyi tau), com as quais somos familiarizados. As mulheres faziam os outros saberem, através de intermediários, que o grupo não estava satisfeito com a perda de trabalho na colheita e seria relu-

${ }^{14}$ Conta-se que um grupo de trabalhadores depois de acordar o vigia que dormia na cabine, mandou-o descer e, usando querosene, atearam fogo em uma máquina.

${ }^{15}$ Rosni, uma viúva, é reconhecida pelo seu trabalho duro e independência enquanto o marido de Rokiah é considerado um fraco, sendo Rokiah considerada a chefe da família, tomando todas as decisões básicas. Tais mulheres, especialmente quando seus filhos já cresceram, são tratadas como homens, sendo dispensadas de grande parte dos requisitos de modéstia e deferência exigidos das mulheres na sociedade malasiana. 
tante em transplantar os campos daqueles que tivessem alugado as máquinas na temporada anterior. Elas também "faziam saber" que, se uma máquina quebrasse no curso da colheita, um fazendeiro que então quisesse concluir sua colheita manualmente não contaria com seus velhos trabalhadores para socorrê-lo.

Quando chegou o tempo, no começo da estação irrigada de 1977, para fazer valer essa ameaça, a discrição mais uma vez prevaleceu. Nenhum dos três grupos se recusou prontamente a transplantar grãos de arroz para aqueles que tinham usado máquinas na estação anterior. Contudo, as mulheres atrasaram o processo de transplante: a líder do grupo dizia ao fazendeiro prejudicado que elas estavam ocupadas e não poderiam trabalhar em suas terras ainda. Somente uma dúzia de fazendeiros tinha usado máquinas na temporada anterior, o que garantia aos grupos de mulheres um grande mercado de trabalho antes de fazer o transplante das colheitas daqueles que não tinham se mecanizado. As mulheres transplantadoras, então, mantiveram suas opções em aberto, evitando uma recusa direta de replante, que teria provocado um rompimento explícito. Sabedores dos rumores do boicote, os fazendeiros que tinham sido preteridos tornaram-se crescentemente ansiosos, já que seus arrozais estavam passando de maduros e eles temiam que sua colheita não se completasse antes da data marcada para que acabasse o suprimento de água. Os ânimos dos fazendeiros que estavam sendo boicotados não melhoraram ao ver os campos dos vizinhos recém-transplantados, próximos aos seus próprios lotes vazios.

Depois de mais de duas semanas dessa guerra de nervos - esse aparente boicote que nunca se anunciou claramente - seis fazendeiros ${ }^{16}$ "fizeram saber", indiretamente, aos participantes do boicote, que estavam fazendo acertos para conseguir trabalhadores de fora para vir e transplantar suas colheitas. Neste ponto, o boicote entrou em colapso. Cada um dos três grupos teve que enfrentar defecções, já que as mulheres temeram perder permanentemente seus trabalhos de transplante para forasteiros. Elas enviaram rapidamente uma carta dizendo que começariam a transplantar a terra dentro dos próximos dias. Três dos seis fazendeiros cancelaram seus acertos com grupos forasteiros, enquanto os outros três foram em frente, acreditando, por um lado, ser muito tarde para suspender os acertos e, por outro lado, querendo ensinar a lição às mulheres. Transplantadores vieram da cidade de Yan (próxima à sede do sistema de irrigação) e de outras localidades mais longínquas, como Singkir e Merbuk. Um fazendeiro, Haji Salim, usando sua considerável influência política, combinou com autoridade locais para trazer um grupo de transplantadores de Thai - uma prática que ele tem continuado e pela qual tem sido duramente criticado.

A tentativa breve e abortiva de parar a mecanização pela ação coletiva foi assunto de desmoralização ou de elogio post-mortem, variando de acordo com o posicionamento adotado pelos indivíduos. Ao lado do prazer ou do desapontamento expresso, o post-mortem convergiu sobre a inevitabilidade do desenlace. Mesmo aqueles com muito a perder com a mecanização perceberam que, se seu blefe funcionasse, seria quase impossível ir além de conversas e de vagas ameaças. Eles concordaram tristemente que "isto seria apenas conversa e que, de qualquer maneira, eles tinham plantado. O que podiam fazer? Ter continuado a recusar a transplantar, uma vez que trabalhadores de fora tinham sido trazidos, teria significado arriscar uma já precária sobrevivência. A futilidade de uma tal recusa foi mais de uma vez caracterizada pelo uso do ditado popular malaio que pode ser entendido como "cuidado para não cortar o galho em que se está sentado"17. Um dos camponeses, que se tornou o quebrador de máquinas local, comentou o ocorrido assim: "os pobres têm que trabalhar de qualquer maneira; eles não podem escapar”. Um saudável interesse em sobreviver requereu deles que engolissem seu orgulho e voltassem ao trabalho. De fato, a possibilidade desse desenlace estava implícita na maneira indireta pela qual o boicote foi conduzido; uma confrontação e um boicote abertos teria significado queimar as pontes atrás deles. Pelo contrário, eles deixaram aberta uma avenida de recuo. Em termos de discurso público, o boicote foi um não-evento, uma vez que nunca foi abertamente declarado ou derrotado, já que o uso dos atrasos e de desculpas pouco plausíveis significava que a mesmo a intenção do boicote poderia ser negada.

\footnotetext{
${ }^{16}$ Os seis eram grandes fazendeiros, segundo os padrões da comunidade, cultivando um total de quase 70 acres. Eles afirmaram em sua defesa que tinham sido pressionados por um compromisso com uma firma para cumprir uma data de transplante de seu grupo, e que só depois de terem sido preteridos outra vez, fizeram alguma coisa.

${ }^{17}$ A tradução literal do ditado popular malasiano é "zangado com seu arroz, jogando-o pelas sua janela dando-o às suas galinhas (marah sama nasi, tauk, bagi ayam makan).
} 
Desse modo, verifica-se que os objetivos da tentativa de greve em Sedaka e em outras inumeráveis comunidades na planície de Kedah eram ambiciosos ${ }^{18}$. As mulheres pretendiam nada menos do que bloquear uma significativa mudança nas relações de produção. Seus meios, como vimos, contudo, eram modestos e disfarçados. Assim, embora tenham falhado em impedir a mecanização da colheita, sua tentativa não foi completamente fútil. Há poucas dúvidas de que as máquinas coletoras teriam sido adotadas mais rapidamente se não tivesse havido sua resistência. Para pobres camponeses, vivendo à margem, o tempo ganho foi vital. Cinco anos após a introdução das máquinas, havia ainda cinco ou seis fazendeiros que contratavam trabalhadores manuais para alguma ou todas as suas colheitas de arroz porque, dizem, seus vizinhos necessitavam de trabalho. Acredita-se que têm sido influenciados pela campanha subterrânea de difamação travadas contra aqueles que invariavelmente usam as máquinas.

\section{O ROUBO DE GRÃOS DE ARROZ: RESISTÊNCIA ROTINEIRA}

A tentativa de deter a mecanização da colheita, embora esteja longe de ter se constituído num alto drama, foi, sem dúvida, algo fora do comum. Ela se colocou contra um passado de resistência raramente notado, referente a salários, arrendamento, aluguéis e à distribuição dos arrozais, uma das características permanentes da vida em Sedaka e de toda área rural estratificada. Um exame acurado de reino de lutas, revela uma forma implícita de sindicalismo que é reforçada tanto pela mutualidade entre os pobres, quanto por uma considerável quantidade de furtos e de violência contra a propriedade. Nenhuma dessas atividades coloca uma ameaça fundamental à base da estrutura de desigualdades, quer seja material ou simbolicamente. O que elas representam, porém, é um constante processo de teste e renegociação das relações de produção entre as classes. Em ambos os lados, no dos proprietários/arrendatários; no dos fazendeiros/trabalhadores, há uma tentativa incessante de aproveitar e salientar cada pequena vantagem, visando verificar os limites das relações existentes, ver precisamente com o que se pode sair à margem e, finalmente, incluir essa margem como uma parte de um território aceito, ou pelo menos tolerado. Depois da década passada, a corrente dessa batalha de fronteira tem, certamente, favorecido de modo consistente as fortunas dos grandes fazendeiros e proprietários. Eles têm não somente englobado grandes pedaços do território defendido pelos trabalhadores assalariados e arrendatários, mas, fazendo isso, têm reduzido (através da marginalização) o perímetro ao longo do qual a batalha continua. Mesmo ao longo desse perímetro reduzido, contudo, há uma constante pressão exercida por aqueles que esperam reconquistar pelos menos uma pequena parte do que, relutantemente, perderam. Os que resistem requerem pouca coordenação explícita na condução dessa luta, porque se recusam a mudar o simples imperativo de garantir um sustento minimamente tolerável.

As dimensões e a condução dessas resistências mais rotineiras poderiam preencher volumosos trabalhos. Para nossos objetivos aqui, porém, a maioria das questões básicas levantadas por esse tipo de resistência pode ser vista numa forma particularmente popular que elas assumem: os furtos de grãos de arroz ${ }^{19}$. Nessa perspectiva, o furto no campo é, em si mesmo, irrelevante, sendo quase que uma marca permanente das comunidades agrárias estratificadas em todos os momentos e lugares em que o estado e seus agentes são insuficientes para controlá-lo, tomando mesmo uma dimensão de luta na qual os direitos de propriedade são contestados, embora possa se tornar um elemento essencial de qualquer que seja o modelo de relações de classes.

O montante de grãos de arroz roubados em uma única temporada, embora não tão grande em relação ao total da colheita, é alarmante para os grandes fazendeiros que acreditam num provável crescimento desse montante. Nenhuma estatística segura está disponível, certamente, mas fiz um esforço para registrar as perdas de grãos de arroz a mim relatadas durante a principal temporada de 79 a 80 . De longe, a maior categoria de furtos era de sacos completos de arroz debulhado, deixados nos campos, à noite,

${ }^{18}$ Em termos da política dos camponeses, o localismo do boicote e a ausência de instituições para reforçá-los no mercado regional de trabalho foram impedimentos devastadores. Assim, as mulheres de Sedaka, ao boicotarem alguns fazendeiros locais, aceitavam trabalhar em outros lugares, servindo, assim, sem ter consciência disso, como fura-greves em outras aldeias de Muda. E, certamente, as mulheres dessas aldeias, ou outras como elas, eram pagas para ajudar a quebrar o boicote em Sedaka. Esse foi um exemplo clássico da fragilidade dos efeitos da solidariedade quando ela é apenas localizada.

${ }^{19}$ Para o exame de outras formas de resistência cotidianas, incluindo outros tipos de furtos, ver SCOTT, J.C. Relações cotidianas de classe, New Haven: Yale Press, capítulo 7. 
durante a colheita. Para um melhor entendimento desses furtos, vejamos o quadro abaixo.

Inicialmente, deve ser ressaltado que a essa perda total deve-se adicionar outra quantidade de arroz que sumiu de outras maneiras. Pelo menos quatro sacos de arroz, secando ao sol em esteiras, desapareceram. Dois muito bem-sucedidos fazendeiros perderam sacos que tinham sido estocados sob suas casas. Foi também relatado que algo como essa mesma quantidade de arroz foi roubada de celeiros ao longo da temporada ${ }^{20}$. Fomos informados também que uma pequena quantidade de arroz foi pega ainda nos arrozais. É impossível, nesse caso, precisar a quantidade, mas pode-se afirmar que ela não é substancial ${ }^{21}$. Finalmente, uma avaliação completa dos furtos de arroz deveria incluir uma estimativa de grãos que, segundo dizem, os debulhadores colocam em seus bolsos e dentro das camisas no fim do dia de trabalho ${ }^{22}$.

Certos fatos sobre o padrão de roubo merecem menção. Inicialmente, com exceção de dois fazendeiros que são moderadamente ricos, todas as vítimas estão entre um terço das famílias mais ricas de Sedaka. Isto indica, simplesmente, o fato óbvio de que tais famílias terão mais arroz

Furtos de Sacos de Arroz, Registrados na Temporada de 1979-80

\begin{tabular}{|l|c|}
\hline \multicolumn{1}{|c|}{ Fazendeiro } & Perda relatada (em sacos) \\
\hline Shahnon & 01 \\
\hline Haji Kadir & 01 \\
\hline Samat & 01 \\
\hline Abu Hassan & 02 \\
\hline Ghani Lebai Mat & 01 \\
\hline Amin & 02 \\
\hline Tok Long & 02 \\
\hline Idris & 01 \\
\hline Lebai Pendek & 02 \\
\hline Fadzil & 01 \\
\hline \multicolumn{1}{|c|}{ TOTAL } & 14 \\
\hline
\end{tabular}

plantado nos campos no período da colheita e que os pequenos proprietários não têm condições de suportar a perda e sofrem para trazer, rapidamente, o arroz debulhado para suas casas. Merece destaque também o fato de que os grandes fazendeiros, com plantações distantes de suas casas, que não podem ser debulhadas (e até armazenadas) em um único dia, são os mais propensos a tais perdas. Mas aqui é significante notar que a forma como acontece o roubo é um produto do padrão de relações de propriedade prevalecentes em Sedaka. O rico, de modo geral, possui o que pode ser tomado, enquanto o pobre tem um grande incentivo de tomá-lo. Ninguém duvida que os homens pobres do local são responsáveis pela grande maioria dos roubos de arroz.

A quantidade total de arroz roubado, talvez entre 20 a 25 sacos de arroz, é menos do que um centésimo do montante de arroz colhido numa safra por todos os fazendeiros da aldeia. Por esta medida, as perdas são até triviais e são geradas por aqueles que produzem um excedente substancial. Se, entretanto, medirmos a significância dessa quantidade de arroz roubada pelo que poderia adicionar ao suprimento de alimentos das poucas famílias mais pobres na aldeia, ela poderia representar uma quantia relevante. É interessante notar que 20 a 25 sacos de arroz é mais do que a metade da quantidade de grãos doados voluntariamente pelos fazendeiros como dízimo islâmico (zakat peribadi) após a colheita. A comparação é oportuna, precisamente porque eu ouvi por duas vezes homens pobres se referindo, sorrindo, a roubos de arroz (curian padi) como "zakat peribadi que alguém toma para si mesmo" (zakat peribadi, angkat sindiri). Essa evidência não é certamente conclusiva, mas é inteiramente possível que alguns dos pobres, de algum modo, considerem tais atos não tanto como roubo, mas como a apropriação do que eles sentem que lhes pertence devido a costumes antigos - uma espécie de imposto dos pobres para substituir os presentes e salários que não mais recebem. Neste sentido, dois outros itens de evidência circunstancial são relevantes. Primeiramente, convém citar um dos fazendeiros que perderam a plantação de arroz. Samat estava entre os mais

\footnotetext{
${ }^{20}$ Os números são imprecisos. Os grãos de arroz são furtados de duas maneiras: quebrando-se tábuas dos celeiros ou fazendo-se furos pelos quais o arroz é retirado. Embora muitos fazendeiros façam, periodicamente, marcas dentro dos silos, é difícil saber precisamente quanto é retirado ao longo do tempo.

${ }^{21}$ Camponeses destacam que o som do debulhamento e do armazenamento seria um problema para o ladrão, enquanto os ricos dizem que ladrões são preguiçosos demais para se submeterem à atividade de debulhar.

22 Tais práticas de surrupiamento são citadas pela maioria dos fazendeiros, mas não tentei calcular quanto arroz é apropriado dessa maneira durante a colheita (Nota do autor).
} 
admirados pelos pobres, por sua relutância em alugar a máquina de colher e debulhar, enquanto todos os outros fazendeiros utilizaram a máquina assim que foi possível. Há também algumas indicações de que os roubos de arroz podem ser usados como uma sanção pelos trabalhadores descontentes. Nesse sentido, Sukur, um dos meus informantes, contou-me em certa ocasião que os fazendeiros receavam contratar debulhadores que, costumeiramente, convidavam, pois algum que fosse esquecido poderia, num momento de raiva, roubar arroz dos campos. Se, de fato, o roubo da plantação de arroz tem um elemento de justiça popular, o escopo de tal resistência tem sido consistentemente reduzido pelo uso das máquinas de colher e debulhar, as quais tornam possível colher e armazenar (ou vender) uma colheita inteira de um fazendeiro num único dia. As máquinas, então, não apenas eliminam a colheita manual, a debulha manual, o transporte dentro da propriedade e o trabalho de colher os grãos derrubados no campo quando da colheita ${ }^{23}$, mas também tendem a eliminar o roubo.

A atitude dos fazendeiros ricos em relação a tais roubos é uma combinação de raiva, como é de se esperar, e também de medo. Por exemplol, Haji Kadir, o fazendeiro mais rico na aldeia, ficou tão furioso com sua perda que chegou a pensar em passar a noite seguinte no campo, guardando sua plantação de arroz com sua pistola. Ele não o fez porque ponderou que o simples rumor de que ficaria à espreita seria suficiente para deter qualquer roubo. O elemento de medo poder ser identificado, em parte, pelo fato de que, em Sedaka, nunca um roubo de plantação de arroz foi denunciado na polícia. Fazendeiros ricos explicaram-me que caso fizessem tal denúncia e indicassem um suspeito, a notícia se espalharia e eles temiam que pudessem ser alvo de mais roubos. Haji Kadir viu, em certa ocasião, alguém roubando um saco de arroz à noite em um campo de um vizinho. Ele não apenas foi incapaz de impedir o roubo, mas também não informou seu vizinho, apesar de estar seguro sobre a identidade do ladrão. Quando lhe perguntei o porquê de tal atitude, ele respondeu que o ladrão, que também o viu, saberia quem seria o informante e roubaria, em seguida, sua plantação. Numa safra anterior, Mat Sarif, outro fazendeiro rico, perdeu dois sacos de arroz, mas contou-me que não queria saber quem o roubou. Velho e um pouco frágil, ele simplesmente acrescentou: "eu tenho medo de ser morto (takut mampus)". Para uma parcela dos pobres mais ousados da localidade, parece que se estabeleceu, com base no terror, algo como um pequeno equilíbrio que viabiliza a continuidade de tais furtos ${ }^{24}$

Outras formas de resistência dos pobres de Sedaka variam na sua especificidade, mas não no contorno geral. Uma marca distintiva de praticamente toda resistência em Sedaka é a relativa ausência de confrontação aberta entre as classes. Onde a resistência é coletiva, ela é cuidadosamente prudente; onde o indivíduo ou pequeno grupo atacam a propriedade, ela é anônima e geralmente noturna ${ }^{25}$. É pela prudência calculada e pelo segredo que se preserva, na maioria das ocasiões, o teatro encenado do poder que domina a vida pública em Sedaka. Qualquer intenção de atacar violentamente o palco pode ser desaprovada e as opções são conscientemente mantidas em aberto. Deferência e conformidade, embora raramente signifiquem uma lisonja servil, continuam a ser posturas públicas dos pobres. Entretanto, a ação de bas-

${ }^{23}$ Esta última atividade é identificada por Scott como "gleaning", palavra de difícil tradução, pois tem nomes específicos em português, de acordo com o tipo de produto agrícola. Por isto, optamos por descrever a atividade e não traduzir por uma expressão única.

${ }^{24}$ Há, entretanto, meios mais sutis de "nomear" o suspeito baseados na forma tradicional de "deixar ser conhecido" (cara sembunyi tau). Um deles consiste em consultar um curandeiro (bomoh) no distrito em que tenha conquistado fama por encontrar coisas perdidas ou identificar ladrões. Após conhecer as particularidades, o bomoh usará encantamentos (jampi) e faz aparecer, por mágica, a forma do ladrão na água preparada especialmente para a ocasião. Não surpreendentemente, o rosto que se forma é geralmente o do homem do qual o cliente sempre suspeitou. No caso de roubo de arroz, o propósito não é tanto recuperar o arroz, mas identificar o ladrão. O fazendeiro, quando retorna para a aldeia, contará para seus amigos as características físicas vistas e descritas pelo bomoh. A notícia se espalhará e o ladrão suspeito saberá que está sendo vigiado, sem que haja uma acusação direta, nem uma denúncia policial. Assim, Haji Kadir relatou que o bomoh disse ter visto Taib e outro homem não identificado na água. Se, de fato, Taib for o culpado, Haji Kadir espera que a difusão da acusação pela redondeza evite qualquer roubo subseqüente na área. Em pelo ao menos duas ocasiões, entretanto, aldeões lembram que alguns ou todo o arroz roubado reapareceu misteriosamente depois de uma consulta ao bomoh. O tipo de circunspecção empregado por estes poucos fazendeiros que recorrem ao bomoh é outra indicação de que uma confrontação aberta é considerada perigosa.

${ }^{25}$ Para um interessante paralelo, veja Thompson, E. P. “O crime do anonimato”, in Hay, D. et al. Albion's Fatal Tree, pp. 255-344. 
tidores pode, claramente, apenas externar um teste contínuo de limites.

A resistência em Sedaka não tem nada do que alguém pode esperar encontrar na história típica do conflito rural. Não há motins, demonstrações, incêndios culposos, banditismo social organizado ou violência aberta. A resistência que descobrimos não está relacionada com movimentos políticos amplos, ideologias, ou nenhuma estrutura revolucionária, embora, sem dúvida, lutas similares tenham ocorrido em quase todas as aldeias da região. Os tipos de atividades encontrados aqui requerem pouca coordenação, para não mencionar organização política, embora estas possam influenciar as ações dos camponeses. Podemos dizer que tais atividades são, em resumo, formas de luta quase que inteiramente voltadas para a esfera local. Desde que sejamos cuidadosos quanto ao uso do termo, essas atividades devem apropriadamente ser chamadas de resistência primitiva. O uso de "primitiva” não implica, como pretendia Hobsbawn, que elas são de algum modo atrasadas e destinadas a serem substituídas por ideologias e táticas mais sofisticadas ${ }^{26}$. Implica, apenas, que essas formas de resistência são estratégias cotidianas permanentes das classes rurais subordinadas que vivem em difíceis condições. Em tempos de crise ou momentos de mudança política, podem ser complementadas por outras formas de luta que são mais oportunas. Entretanto, elas não desaparecerão enquanto a estrutura rural social se mantiver exploradora e desigual. Assim, essas estratégias são o alicerce obstinado sob o qual outras formas de resistência devem crescer e tendem a persistir após outras formas de resistir terem falhado, ou após produzir-se, por sua vez, um novo padrão de desigualdade.

\section{O QUE CONSIDERAR COMO RESISTÊNCIA}

Podem as atividades que descrevemos e outras similares serem consideradas de formas de resistência? Podemos considerar um boicote, que nunca foi anunciado, como uma forma de resistência de classe? Por que devemos considerar o roubo de alguns sacos de arroz como uma forma de resistência de classe, se nele não há ação coletiva, tampouco um enfrentamento aberto ao sistema de propri- edade e dominação? Muitas das mesmas questões podem ser levantadas com relação à fofoca e à difamação de pessoas, que são alguns dos principais meios dos pobres de Sedaka, consistentemente, tentarem influenciar o comportamento dos ricos.

Como uma primeira aproximação, proponho abaixo uma definição para a resistência dos camponeses, a qual poderia incluir muitas das atividades que temos discutido. O propósito implícito desta definição não é estabelecer importantes questões com força de lei, mas antes ressaltar os problemas conceituais que enfrentamos em compreender a resistência e desenvolver, de modo plausível, uma compreensão mais ampla do termo.

Micro-resistência entre camponeses é qualquer ato de membros da classe que tem como intenção mitigar ou negar obrigações (renda, impostos, deferência) cobradas à essa classe por classes superiores (proprietários de terra, o estado, proprietários de máquinas, agiotas ou empresas de empréstimo de dinheiro) ou avançar suas próprias reivindicações (terra, assistência, respeito) em relação às classes superiores.

Três aspectos da definição apresentada merecem um breve comentário. O primeiro, o fato de que não há nenhuma exigência de que a resistência assuma a forma de ação coletiva. O segundo, que tem gerado muita polêmica, é a incorporação das intenções à definição. Posteriormente, abordaremos este problema novamente, bastando dizer agora que a formulação como encontrada na definição permite afirmar que muitos atos intencionais de resistência podem suscitar e produzir conseqüências inteiramente imprevisíveis. Finalmente, o reconhecimento expresso na definição do que é que chamamos de resistência simbólica ou ideológica (fofoca, injúrias, rejeição de categorias impostas, questionamento e afastamento da deferência) como uma parte integral da resistência baseada na diferenciação de classe.

O problema das intenções é bastante complexo, não simplesmente porque os ainda não apreendidos roubos de arroz de nosso exemplo anterior são difíceis de serem identificados, mas também porque a discussão de suas intenções somente se torna possível quando os próprio roubos são localizados. A nossa dificuldade em entender o significado de atos como os furtos de arroz relaciona-se com

${ }^{26}$ Veja Hobsbawn, E. J., Primitive Rebels: studies in Archaic Forms of Social movement in the 19th and 20th Centuries New York: Norton, 1965. A narrativa iluminadora de Hobsbawn é, ao meu ver, sobrecarregada excessivamente com uma teoria unilinear da história das classes subordinadas, que afirma ser toda forma de resistência primitiva destinada à superação, no devido tempo, por uma forma mais progressiva, até que até uma visão marxista - leninista madura seja alcançada. 
nossa tendência de pensar a resistência como ações que envolvem, ao menos, algum sacrifício individual ou coletivo de curta duração, propiciando, assim, algum ganho coletivo de longo alcance. As perdas imediatas de uma greve, de um boicote, ou até a rejeição de competir com outros membros de uma classe por terra ou trabalho são casos em discussão. Quando acontecem atos como roubo, entretanto, encontramo-nos diante de uma combinação que pode ser entendida como de ganho individual imediato ou como de resistência. Como podemos, então, julgar quais dos dois propósitos é, em última instância, decisivo? O que está em debate aqui não é uma questão menor de definição, mas antes a interpretação de uma série de ações que, ao meu ver, reside, historicamente, no coração das relações cotidianas de classe. Ilustrando tais afirmativas, convém lembrar que os ingleses que caçavam ilegalmente em florestas no século XVIII, poderiam estar resistindo aos impostos pelo uso de recursos selvagens da propriedade ou estavam apenas interessados em um cozido de coelho. Por outro lado, o camponês do Sudeste asiático que esconde seu arroz e posses dos coletores de impostos, pode estar protestando contra altos impostos, mas, concomitantemente, adota uma forma de garantir arroz suficiente até a próxima safra. Por sua vez, um camponês que deserta do exército, pode ser um opositor da guerra ou, de modo equivalente, estar apenas salvando a sua pele ao escapar da frente de batalha. Quais desses motivos fundidos e inextricáveis podem ser considerados proeminentes? Certamente, se fizermos essa pergunta aos atores envolvidos e se, candidamente, puder haver uma resposta, não é difícil que eles sejam incapazes de identificar uma determinação clara de suas intenções.

Sendo assim, estudiosos de escravidão, que têm enfrentado mais diretamente essa dubiedade, quando identificam que alguns atos de protesto velado, como a acomodação e os roubos, eram freqüentemente a única opção disponível, tendem a considerá-los como formas de resistência "real". Na análise de Gerald Mullin sobre o caráter protestador do escravo, são apresentadas três razões para interpretar assim os atos mencionados:

Ao acessar essas diferenças observáveis do comportamento escravo, estudiosos normalmente perguntam se uma rebelião particular representa resistência aos abusos da escravidão ou resistência real à própria escravidão. Quando o comportamento do escravo é examinado à luz do conteúdo político, os trabalhadores inferiores, os escravos do campo, dão-se muito mal. De modo geral, sua acomodação e o roubo representavam um limitado e, talvez, auto-indulgente tipo de rebelião.
Suas reações a abusos inesperados ou a mudanças bruscas na rotina da plantação foram, no máximo, apenas pequenos atos contra a escravidão. Mas as ações sistemáticas e organizadas dos escravos para obstruir o trabalho da plantation - seus atos persistentes de atrito contra colheitas e armazéns, e os roubos cooperativos noturnos que sustentavam o mercado negro - eram muito mais 'políticos' em suas conseqüências e representavam resistência à própria escravidão (Mullin, 1972: 35, ênfase adicionada).

Apesar da posição de Eugene Genovese (1974) sobre estas formas de resistência diferir da apresentada acima em importantes pontos, ele insiste em distinguir entre formas de resistência "pré-políticas" e formas de resistência mais significantes contra o regime de escravidão. A distinção para ele, como indica a seguinte citação, reside tanto no reino das conseqüências quanto na realidade das intenções.

Estritamente falando, apenas a insurreição representou uma ação política, que alguns decidiram definir como a única resistência genuína, considerando que apenas ela representou diretamente um desafio ao poder do regime. Deste ponto de vista, aquelas atividades que outros chamaram "resistência cotidiana à escravidão" - roubo, mentira, dissimulação, vagabundagem, assassinato, infanticídio, suicídio, incêndio culposo - qualificam-se, no máximo, como pré-políticas e, no mínimo, como apolíticas... Mas a 'resistência cotidiana à escravidão' geralmente implica acomodação e não faz sentido, com exceção da situação em que normas de um status quo legitimado tenham, segundo a percepção e definição dos escravos, sido violadas (Genovese, 1974: 598).

Combinando estas perspectivas sobrepostas, o resultado é algo como uma dicotomia entre a resistência real e as atividades incidentais ou até epifenomênicas. A resistência "real" é definida como (a) organizada, sistemática e cooperativa; (b) baseada em princípios ou egoístas; (c) eficazes em termos de conseqüências revolucionárias e/ou (d) englobadora de idéias ou intenções que negam as bases da dominação. As micro-atividades, incidentais ou epifenomênicas, em contraste, são (a) não organizadas, não sistemáticas e individuais; (b) oportunísticas e "auto-indulgentes”, (c) inócuas em termos de conseqüências revolucionárias, e/ou (d) implicam, em sua intenção ou lógica, uma acomodação ao sistema de dominação. Convém esclarecer que estas distinções são importantes para qualquer análise que tenha como objetivos a tentativa de delinear as várias formas de resistência e de mostrar como elas estão relacionadas a uma ou outra forma de dominação

Raízes, Campina Grande, vol. 21, nº 01, p. 10-31, jan./jun. 2002 
na qual ocorrem. Minha maior discordância é com a argumentação de que as últimas formas são, em última instância, triviais ou inconseqüentes, enquanto apenas as primeiras podem constituir resistência real. Esta posição, ao meu ver, deforma, fundamentalmente, a própria base da luta econômica e política conduzida diariamente pelas classes subordinadas. Ainda pode ser acrescentado que esta posição baseia-se numa combinação irônica de pressupostos leninistas e burgueses a respeito do que constitui a ação política. Os três primeiros termos de comparação da tipologia acima sugerida serão tratados a seguir. $\mathrm{O}$ item final, referente aos julgamento das intenções, e a tentativa de classificá-las como acomodativas ou revolucionárias, demandaria uma longa e separada análise.

Inicialmente, vejamos a questão das ações que são “auto-indulgentes", individuais e não organizadas. Imersa na lógica de Genovese (1974) e, especialmente, na de Mullins (1972), está a pressuposição de que tais atos, intrinsecamente, carecem de conseqüências revolucionárias. Este pode ser o caso, mas também é pertinente considerar que raramente existe uma revolução moderna que pode, com sucesso, ser explicada sem referência a tais atos, quando eles acontecem em escala massiva. Tomaremos novamente o assunto da deserção militar e o papel que desempenha nas revoluções, acreditando que a revolução russa é um caso exemplar. A crescente deserção do grande batalhão camponês do exército czarista, no verão de 1917, foi uma parte importante e indispensável do processo revolucionário, pelo menos em dois aspectos: os desertores foram responsáveis pelo colapso da principal instituição de repressão do estado czarista - uma instituição que tinha anteriormente, em 1905, derrubado outro levante revolucionário e, conseqüentemente, contribuíram diretamente para o processo revolucionário no campo ao participar nas mensurações de terra por todas as províncias da Rússia
Européia. É extremamente nítido que a sangria nas forças czaristas foi grandemente "auto-indulgente", "desorganizada", e "individual" - embora milhares e milhares de indivíduos tenham abandonado suas armas e se dirigido para casa ${ }^{27}$. O ataque à Áustria foi esmagado com enorme perda de tropas e oficiais; a ração de pão foi reduzida e "dias de jejum" foram inaugurados no fronte; os soldados sabiam, além do mais, que se ficassem, perderiam a chance de ganhar com a partilha da terra no campo ${ }^{28}$. A deserção ofereceu aos camponeses alistados a possibilidade de salvar suas peles e retornar para casa enquanto pão e, agora terra, eram disponíveis. Desde que a disciplina no exército fora dissolvida, os riscos eram mínimos. Dificilmente pode-se imaginar um conjunto de objetivos mais “auto-indulgentes”. Mas foram justamente os fins autoindulgentes, praticados por massas desorganizadas de soldados camponeses "auto-desmobilizados", que tornaram a revolução possível (Carr, 1966).

A desintegração do exército czarista é uma das muitas instâncias em que a agregação de pequenos atos auto-indulgentes de insubordinação ou deserção, sem intenção revolucionária, criou uma situação de revolução. A dissolução dos exércitos nacionalistas de Chaing Kai-Shek, em 1948, ou a do exército de Saigon, em 1975, poderiam sem dúvida ser analisadas a partir de parâmetros similares. E muito antes do desfecho final, deve ser adicionado que atos de insubordinação em cada exército, assim como no exército americano servindo no Vietnã, tiveram forte influência sobre o que as forças contra-revolucionárias poderiam esperar e requerer de seu próprios soldados $\operatorname{rasos}^{29}$. Resistência desse tipo certamente não é não um monopólio da contra-revolução, como George Washington e Emiliano Zapata, entre outros, descobriram. Podemos imaginar que a lógica eminentemente pessoal de Pedro Martinez, um soldado das forças zapatistas, não foi marcadamente dife-

\footnotetext{
${ }^{27}$ Veja Allan Wildman. "The February Revolution in the Russian Army". Soviet Studies. Vol. 22. n ${ }^{\circ}$ 1, July 1970, pp. 3-23; Marc Ferro. "The Russian Soldier" in 1917: undisciplined, Patriotic, and Revolutionary, Slavic Review, Vol. 30, No.3 (Sept. 1971), pp. 483-512; Barrington Moore, Injustice. White Plains, New York: M.E. Sharpe, 1978), p. 364, and Theda Skopol. States and Social Revolutions Cambridge: Cambridge University Press, 1979, pp. 135-8. Há um consenso de que a propaganda bolchevista na frente de batalha não foi um instrumento para provocar tais deserções. There is a consensus that Bolshevik propaganda at the front was not instrumental in provoking these desertions.

${ }^{28}$ Pode-se considerar as mensurações de terra e o saque de propriedades da aristocracia como um ato revolucionário, e, foi certamente revolucionário em suas conseqüências em 1917. Mas foi um evento largamente espontâneo, fora do controle de qualquer partido e é extremamente improvável que aqueles que se apossaram da terra percebiam a si mesmos como construindo um governo revolucionário, menos ainda um bolchevique. Veja Skocpol, op. Cit., pp. 135-138.

${ }^{29}$ O sucesso inicial do Solidariedade, na Polônia, pode, de modo similar, ser atribuído amplamente ao fato de que o regime impopular não poderia contar com seu próprio exército para, ativamente, reprimir a população civil em rebelião, sendo, portanto, forçado a se apoiar na odiosa polícia paramilitar, os 'Zomos'.
} 
rente daquelas dos soldados czaristas que deixaram o fronte.

Foi onde (batalha de Tizapán) eu finalmente decidi. A batalha foi horrível. O tiroteio foi tremendo. Foi uma batalha muito sangrenta, de três dias e três noites. Participei um dia e fui embora. Abandonei o exército... Eu disse para mim mesmo: "É tempo agora de voltar para minha esposa, minhas crianças pequenas. Eu estava saindo"... Eu disse para mim mesmo: "Não. Minha família em primeiro lugar e eles estão passando fome. Agora eu vou embora” (Lewis, 1964: 102).

A sinceridade de Pedro Martinez serve para nos lembrar que não há um relacionamento necessário entre a trivialidade do ato de autopreservação e de cumprir as obrigações familiares e a trivialidade das conseqüências de tais atos. Ações que não poderiam de forma alguma ser considerados 'políticas', quando multiplicadas, podem ter conseqüências as mais massivas tanto para estados quanto para exércitos.

A questão aqui não se resume, de nenhuma forma, apenas à deserção de exércitos, caso escolhido apenas como uma ilustração diagnóstica. Implica quase toda força similar da tradição camponesa de driblar o roubo e as formas de exploração do trabalho; as conseqüências de tais atos de auto-ajuda podem estar muito além da proporção das intenções minúsculas dos próprios atores.

Considerando que as conseqüências do comportamento de autoproteção são essenciais a qualquer análise mais ampla de relações de classe ou do estado, não quero defender que a resistência poderia ser definida com referência apenas às suas conseqüências. Tal visão incorre, em si mesma, em dificuldades formidáveis, devidas, senão por outra razão, à "lei de conseqüências não intencionadas". Então, qualquer definição de resistência requer alguma referência às intenções dos atores. $\mathrm{O}$ problema com os conceitos existentes de resistência não é, conseqüentemente, que ele tenha inevitavelmente que lidar com intenções e significados, como também com conseqüências. Diferentemente, o problema reside numa insistência ingênua, estéril e mal conduzida em distinguir atos individuais 'auto-indulgentes' de ações presumivelmente não egoístas, coletivas, baseadas em princípios, o que, freqüentemente, resulta na exclusão das primeiras da categoria de resistência real. Insistir em tais distinções como um meio de comparar formas de resistên- cia e suas conseqüências é uma coisa; mas usar essas distinções como um critério básico para determinar o que constitui resistência é perder o mais florescente da política camponesa.

Não é coincidência que os gritos por "pão", "terra" e "contra impostos", que tão freqüentemente residem no coração da rebelião camponesa, estão todos associados às necessidades de sobrevivência material básica da unidade familiar camponesa. Tampouco deve ser algo mais que um lugar comum que a política, a resistência e a submissão camponesa cotidiana, fluem das mesmas necessidades materiais fundamentais. Precisamos compreender o desejo compreensível da família camponesa de sobreviver, visando garantir a segurança física, suprimentos de alimentos, e uma renda monetária suficiente, e identificar a fonte de sua resistência às demandas das gangues de pressão, dos coletores de impostos, dos fazendeiros e empregadores.

Ignorar o elemento de auto-interesse na resistência camponesa é ignorar o contexto determinado não apenas da política camponesa, mas da política da maioria das classes subalternas. É precisamente a fusão entre auto-interesse e resistência que se mostra como uma força vital, animando a resistência de camponeses e proletários. Assim, cabe esclarecer que quando o camponês esconde parte de sua colheita para evitar pagar impostos, ele está tanto enchendo sua barriga quanto destituindo o estado de grãos ${ }^{30}$. Por sua vez, quando um soldado camponês deserta do exército porque a comida é ruim e sua colheita em casa está madura, ele está tanto cuidando de si mesmo quanto negando a artilharia ao estado. Em suma, quando tais atos são raros e isolados, eles são de pouco interesse, mas no momento em que eles se tornam um padrão consistente, embora não coordenado, estamos lidando com resistência. A natureza intrínseca e, em certo sentido, a "beleza" de muitas expressões da resistência camponesa é o fato de, freqüentemente, conferir vantagens imediatas e concretas e, ao mesmo tempo, negar recursos às classes apropriadoras, sem requerer pouca ou nenhuma organização explícita. A obstinação e a força de tal resistência decorrem diretamente do fato de que ela é firmemente enraizada na luta material vivenciada e partilhada por uma classe.

Exigir que a resistência das classes inferiores seja, de algum modo, "orientada por princípios" ou "altruísta” não é apenas uma difamação do status moral das necessida-

${ }^{30}$ Tal resistência não é, certamente, o monopólio das classes subordinadas. A sonegação de impostos e a chamada economia "negra”, em países capitalistas avançados, também são formas de resistência, embora implementadas com mais vigor e sucesso por classes médias e pela elite. 
des humanas essenciais. Fundamentalmente, é mais uma construção equivocada das bases da luta de classe que constituem, primeiramente, uma luta pela apropriação de trabalho, produção, propriedade e impostos. As questões "pão e manteiga" são a essência da política das classes subordinadas e da sua resistência. O consumo, desta perspectiva, é tanto o objetivo quanto o resultado da resistência e contra-resistência. Como Utsa Patnaikv (1979: 398-9) notou, "o consumo não é nada mais do que o histórico 'trabalho necessário', a porção de produção líquida retida pelos pequenos produtores como resultado de sua luta com as classes apropriadoras de lucro”. Este é, então, o coração do auto-interesse da luta de classe cotidiana: a luta defensiva permanente de mitigar ou vencer a apropriação. Pequenos roubos de grão ou furtos no espaço do debulhador podem, do ponto de vista das vantagens, expressar mecanismos de "adaptação" triviais, mas, de um ponto de vista mais amplo das relações de classe, o modo como a colheita é realmente dividida emerge como ponto central.

Uma vantagem do conceito de resistência que começa com necessidades materiais de auto-interesse é que ele avança em apreender que "classe" é, primeiramente, uma experiência dos próprios atores históricos. Aqui subscrevo em gênero, numero e grau a proposição de E.P. Thompson, baseada em sua análise convincente da história da classe trabalhadora, assim formulada:

Em minha visão, tem-se dedicado uma atenção teórica excessiva (grande parte da mesma é claramente a-histórica) à classe e muito pouco à "luta de classes". Na realidade, luta de classes é um conceito prévio assim como muito mais universal. Para expressá-lo claramente: as classes não existem como entidades separadas, que olham ao redor, encontram uma classe inimiga e começam logo a lutar. Pelo contrário, as pessoas se encontram em uma sociedade estruturada de modos determinados (crucialmente, mas não exclusivamente, em relações de produção), experienciam a exploração (ou a necessidade de manter o poder sobre os explorados), identificam pontos de interesse antagônicos, começam a lutar por estas questões e no processo de luta se descobrem como classe, chegando a conhecer esse descobrimento como consciência de classe. A classe e a consciência de classe são sempre as últimas, não as primeiras, fases do processo histórico real (Thompson, 1978: 149).

A tendência para desconsiderar atos 'individuais' de resistência como insignificantes e reservar o termo de "resistência” para ações coletivas ou organizadas é uma orientação equivocada, assim como a ênfase na ação "orientada por princípios”. O status privilegiado atribuído a movimentos organizados, eu suspeito, flui de duas orientações políticas: uma, essencialmente leninista, que trata a única ação de classe plausível como aquela que é conduzida por um partido de vanguarda, servindo como um "comitê central"; a outra orientação trata das ações mais diretamente derivadas da familiaridade e da preferência por política aberta e institucionalizada, como conduzida em democracias capitalistas. Em cada caso, entretanto, há uma compreensão errônea das circunstâncias sociais e políticas nas quais a resistência camponesa geralmente ocorre.

O caráter individual e freqüentemente anônimo de muitas expressões da resistência camponesa é, certamente, um objeto adequado para a sociologia da classe, campo do qual essas expressões emergem. A dispersão em pequenas comunidades e, em geral, a falta de meios institucionais para agir coletivamente favorecem o emprego daqueles meios de resistência que são locais e requerem pouca coordenação. Sob circunstâncias históricas especiais de esmagadora pauperização material, de desorganização das instituições de repressão ou da proteção da liberdade política (mais raramente todas as três), o campesinato pode e tem se tornado um movimento de massa organizado e político. Tais circunstâncias são, entretanto, extremamente raras e, normalmente, de vida curta. Em muitos lugares, na maioria das vezes, estas opções políticas têm sido, simplesmente, obstruídas. Embora a propensão por formas de resistência que são individuais e oportunas não é o que um marxista poderia esperar de pequenos produtores de mercadorias e de trabalhadores rurais, é preciso reconhecer que esses tipos de resistência têm também certas vantagens.

Diferentemente das organizações formais hierárquicas, não há centro, liderança, ou estrutura identificável, passíveis de serem cooptados ou neutralizados. O que falta em termos da coordenação central é compensado pela flexibilidade e persistência. Essas formas de resistência podem não ganhar batalhas premeditadas, mas são admiravelmente eficientes em campanhas de confronto de longo prazo.

Se limitarmos nossa procura por resistência camponesa às atividades organizadas formalmente, procuraremos largamente em vão, pois na Malásia, e em muitos outros países do terceiro mundo, além de ser baixo o nível de organização no meio rural, as entidades que existem, são, freqüentemente, criadas pelas elites rurais e oficiais. Adotando essa abordagem, simplesmente perderemos muito do que está ocorrendo. A atividade política formal deve ser 
a norma para as elites, a inteligentsia, e as classes médias do terceiro mundo, assim como do ocidente, que têm um quase monopólio do acesso às ferramentas institucionais, mas seria também ingênuo esperar que a resistência camponesa possa normalmente ter a mesma forma.

Também não devemos esquecer que as formas da resistência camponesa não são apenas o produto da ecologia social do campesinato. Os parâmetros da resistência também são estabelecidos, em parte, pelas instituições da repressão. Na medida em que tais instituições fazem, efetivamente, seu trabalho, podem evitar qualquer forma de resistência que não seja individual, informal e clandestina. Então, é perfeitamente legítimo - até importante - distinguir entre vários níveis e formas de resistência (formal/ informal; individual/coletiva; pública/anônima; que desafiam o sistema de dominação/que objetivam ganhos marginais). Mas deve, simultaneamente, ficar claro que o elemento a ser realmente medido é o nível de repressão que estrutura as opções que estão disponíveis. Dependendo de circunstâncias que enfrentam, os camponeses devem oscilar de atividades eleitorais organizadas a confrontações violentas, a atos anônimos e silenciosos de "fazer corpo mole" e de roubar. Esta oscilação pode, em alguns casos, ser explicada por mudanças na organização social do campesinato. Mas isto não é tudo! Tal oscilação pode ser mais determinada pelas mudanças no nível de repressão. Algumas vezes o campesinato tem reduzido brutalmente a atividade política aberta e radical em favor de atos de resistência micros e esporádicos. Classificar somente os atos abertos e radicais como resistência, significa aceitar que a estrutura de dominação defina para nós o que é o que não é resistência.

Muitas das formas de resistência que temos examinado podem ser ações "individuais", mas isto não significa que elas não são coordenadas. Aqui, novamente, um conceito de coordenação, derivado de cenários formais e burocráticos, é de pouca ajuda para compreender ações em pequenas comunidades, as quais, historicamente, têm redes informais densas, profundas e sub-culturas ricas de resistência a demandas externas. Por exemplo, não é exagero afirmar que muito da cultura folk da "pequena tradição" camponesa soma-se, precisamente, à legitimação, ou até à celebração, de formas sábias e evasivas de resistência que temos examinado. Nesta e em outras formas (por exemplo, estórias de bandidos, heróis camponeses e mitos religiosos), a sub-cultura camponesa ajuda a subli- nhar a dissimulação, a invasão de propriedade alheia, o roubo, a sonegação de impostos, a fuga de recrutamento e assim por diante. Enquanto a cultura folk não é coordenada no sentido formal, ela freqüentemente alcança um "clima de opinião" que, em sociedades mais institucionalizadas, requereriam uma campanha de relações públicas. O que merece destaque na sociedade camponesa é a extensão em que uma longa série de atividades complexas, que abrange desde a troca de trabalho, a mudança de casa, as preparações de casamento e até as festas, é coordenada por redes de negociações e práticas. $\mathrm{O}$ mesmo ocorre com os boicotes, com as negociações de salários, com a recusa de arrendatários de competirem entre si e com a conspiração do silêncio que circunda os roubos. Nenhuma organização formal é criada porque nada se exige, e, assim mesmo, uma forma de coordenação é alcançada, alertando-nos para o fato de o que está acontecendo não é apenas ação individual.

À luz dessas considerações, então, retornaremos brevemente para a questão das intenções. Para muitas formas de resistência camponesa, temos toda razão de esperar que os atores permanecerão mudos sobre suas intenções. Sua segurança deve depender do silêncio e do anonimato; o tipo de resistência por si mesmo deve depender, para sua efetividade, da aparência da conformidade; suas intenções devem estar, assim, incorporadas à subcultura camponesa e à luta rotineira e normal para garantir a subsistência e a sobrevivência da unidade familiar, de modo a mantê-la inarticulada ${ }^{31}$.

Em um certo sentido, obviamente, as intenções dos indivíduos estão inscritas nos próprios atos. Um soldado camponês que, como outros, deserta do exército, está efetivamente dizendo, através desse ato, que o propósito da instituição, bem como seus riscos e o sofrimento que ela impõe, não prevalecem sobre as necessidades pessoais ou familiares. Colocando em outros termos, o estado e seu exército falharam seriamente em controlar este assunto específico na própria instituição, de modo a reter a subordinação do soldado. Um trabalhador safrista que rouba arroz de seu empregador está “dizendo" que sua necessidade por arroz tem prioridade sobre os direitos de propriedade formais de seu chefe.

Quando abordamos cenários sociais nos quais os interesses materiais das classes apropriadoras estão diretamente em conflito com os do campesinato (rendas, salários, emprego, impostos, recrutamento e a divisão da

${ }^{31}$ Os peixes não conversam sobre a água!

Raízes, Campina Grande, vol. 21, nº 01, p. 10-31, jan.jjun. 2002 
colheita) podemos, ao meu ver, inferir algo sobre as intenções, a partir da natureza das próprias ações. Este é especificamente o caso, quando há um padrão sistemático de ações que mitigam ou negam uma reivindicação. Evidências sobre intenções são, sem dúvida, sempre bem vindas, mas não devemos esperar muito. Por esta razão, a definição de resistência dada anteriormente atribui ênfase especial ao esforço de questionar as reivindicações materiais e simbólicas das classes dominantes. O objetivo, afinal, da grande expressão da resistência camponesa não é diretamente derrubar ou transformar o sistema de dominação, mas, sobretudo, sobreviver - hoje, esta semana, esta estação - dentro dele. O objetivo comum dos camponeses, como Hobsbawn tão habilmente definiu, é "trabalhar o sistema no sentido das desvantagens mínimas” (1973:12). Assim, são conseqüências possíveis da persistente tentativa dos camponeses de se apropriarem de pequenas porções: o alívio, marginal, da exploração; a ampliação dos limites da renegociação das taxas de apropriação; a mudança do percurso do desenvolvimento subseqüente e, mais raramente, a contribuição para a derrocada do sistema. Há, inclusive a possibilidade de que a ação dos camponeses resulte em efeitos contrários às suas intenções de sobrevivência e de persistência. A luta por estas finalidades requer, dependendo das circunstâncias, a micro-resistência, como vimos, ou ações mais dramáticas de auto-defesa.

Em qualquer caso, muitos dos esforços dos camponeses serão vistos pelas classes apropriadoras como truculência, fraude, vagabundagem, furto ou arrogância em resumo, todas as etiquetas planejadas para denegrir as muitas faces da resistência. A definição das classes apropriadoras pode, outras vezes, transformar algo que diz respeito somente à luta não reflexiva pela subsistência num ato de rebeldia.

Deve ficar claro que resistência não é simplesmente qualquer coisa que os camponeses fazem para manter a si próprios e as suas famílias. Muito do que eles fazem é compreendido como aquiescência, embora com aversão. Sobreviver como trabalhadores ou produtores de mercadorias em pequena escala pode impelir alguns a salvarem sua própria pele às custas das de seus colegas. O trabalhador pobre e sem terra, que rouba arroz de outro homem pobre ou que o sobretaxa pelo arrendamento, está sobrevivendo, mas certamente não está resistindo no sentido aqui definido. Uma das questões chaves que devem ser colocadas sobre qualquer sistema de dominação é em que medida ele é eficaz em re- duzir a ação dos indivíduos das classes subordinadas a estratégias puramente auto-referentes, destinadas a garantir sua sobrevivência. Certas combinações de atomização, terror, repressão e pressão de necessidades materiais podem, de fato, alcançar o mais elevado sonho de dominação: ter os dominados explorando-se uns aos outros.

Ao entender como resistência apenas essas estratégias de sobrevivência que negam ou mitigam reivindicações das classes de apropriação, deparamo-nos com uma vasta série de ações a considerar. Tal variedade oculta uma continuidade básica, que reside na história do esforço persistente dos relativamente autônomos produtores de mercadorias de pequena escala, no sentido de defender seus interesses físicos e materiais e de reproduzirem a si próprios. Em diferentes tempos e lugares, eles têm se defendido contra a corvéia, as taxas, o recrutamento do estado agrário tradicional, o estado colonial, as agressões do moderno estado capitalista (por exemplo, rendas, juros, proletarização, mecanização) e, deve ser adicionado, contra muitos estados pretensamente socialistas. A revolução socialista, quando ocorre, pode eliminar muitos dos piores males do regime antigo, mas, raramente, ou até nunca, foi o fim da resistência camponesa. As elites radicais que capturaram o Estado terão em mira objetivos diferentes daqueles dos camponeses que os apoiaram anteriormente. Enquanto o campesinato apega-se a sua pequena parcela, elas podem vislumbrar uma agricultura coletivizada. Enquanto o campesinato é devotado à autonomia local, elas podem querer uma estrutura política centralizada. Finalmente, eles podem querer taxar o campo de modo a industrializá-lo e certamente desejarão reforçar o estado versus a sociedade civil. Conseqüentemente, torna-se possível para um observador astuto como Goran Hyden (1980), encontrar paralelos notáveis entre a resistência inicial do campesinato da Tanzânia ao colonialismo e ao capitalismo e sua resistência corrente às instituições e políticas do atual estado socialista da Tanzânia (Hyden, 1980). Esse autor fornece uma pungente narrativa de como o "modo de produção camponês" - através de estratégias como "fazer corpo mole", privatizar o trabalho e a terra que foi apropriada pelo estado, através da evasão, fuga e da captura de programas governamentais para seus próprios propósitos - tem obstruído os planos do estado. De modo semelhante no Vietnã, após a revolução ter sido consumada no sul, assim como no norte, formas cotidianas de resistência camponesa continuaram. A expansão clandestina de lotes pri- 
vados, a retirada de trabalho das empresas estatais para a produção familiar, a falência da entrega da produção de grãos e dos rebanhos ao estado, a "apropriação" dos créditos e recursos estatais pelas famílias e turmas de trabalho e o crescimento constante do mercado negro atestam a tenacidade da produção de mercadorias de pequena escala sob as formas do estado socialista. As formas de resistência obstinadas, persistentes e irredutíveis que temos examinado devem, então, representar as armas verdadeiramente duráveis dos fracos antes e depois da revolução.

\section{REFERÊNCIAS BIBLIOGRÁFICAS}

ADAS, M. 1981. "From Avoidance to Confontation: Peasant Protest in Precolonial and Cvolinial Southest Asia", Comparative Studies in Societies and History, Vol. 23, No. 2, Abril, pp. 217-47.

BATES, R. 1981. Markets and States in Tropical Africa: The Political Basis of Agricultural Policies, Berkeley: University of California Press.

CARR, E. H. 1966. The Bolshevik Revolution: 1917-1923, Vol. 1, Harmondsworth: Penguin.

COBB, R. C. 1970. The Police and the People: French Popular Protest, 1789-1820. Oxford: Clarendon Press.

DAVIES, R. W. 1980. The Socialist Offensive: The Collectivisation os Soviet Agriculture, 1928-1930. London: MacMillan.

FERRO, M. 1971.”The Russian Soldier in 1917: Undisciplined, Patriotic, and Revolutionary", Slávic Review, Vol. 30, No. 3, Sept.

GENOVESE, E. 1974. Roll, Jordan, Roll. New York: Phanteon Books.

GHEE, L. T. 1977. Peasants and their Agricultural Economy in Colonial Malaya, 1874-1941. Kuala Lumpur: Oxford University Press.

HOBSBAWM, E. J. \& RUDE, G. 1968. Captain Swine. New York: Phanteon Books.
HOBSBAWM, E. 1965. Primitive Rebels: Studies in Archaich Forms of Social Movement in the 19th and $20^{\text {th }}$ Centuries. New York: Norton.

HOBSBAWM, E. 1973. "Peasants and Politics", Journal of Peasant Studies, Vol. 1, No. 1.

HIDEN, G. 1980. Beyond Ujamaa in Tanzania. London: Heinemann.

LEWIS, ${ }^{\circ}$ 1964. Pedro Martinez: A Mexican Peasant and his Family. New York: Vintage Books.

MARX, K. 1970. Capital. Vol. 1. London.

MOORE, B. Jr. 1966. The Social Basis of Dictatorship and Democracy. Boston: Beacon Press.

MOORE, B. 1978. Injustice. White Plains, New York: M. E. Sharpe.

MULLIN, G. 1972. Flight and Rebellion. New York: Oxford University Press.

NONINI, D. M.; DIENER, P. \& ROBKIN, E. E. 1979. 